\title{
Palaeoecology and palaeogeographic relations of the Silurian phragmoceratids (Nautiloidea, Cephalopoda) of the Prague Basin (Bohemia)
}

\author{
ŠTĚPÁN MANDA
}

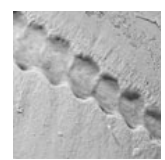

\begin{abstract}
Phragmoceras and Tubiferoceras are discosorid nautiloid genera with endogastric cyrtoconic to orthoconic breviconic shells possessing a contracted aperture. Because of the constricted aperture phragmoceratids have usually been considered as microphages. The constriction of the aperture appears during the late ephebic stage. Preceding ontogenetic stages possessed a brevicone shell with an open aperture, usually considered to be indicative of nectobenthic predatory lifestyle. The apertural constriction probably improved hydrodynamic control and served as protection for the soft body. Attachment sites for distinct retractor muscles suggest evidence of potentially fast movement of the head-arm complex out of the aperture with consequent capture of larger prey. Phragmoceratids are a characteristic component of Silurian nautiloid faunas, which inhabited the mainly tropical carbonate platforms of Baltica and Laurentia. Phragmoceratids closely related to those of the Baltic and Avalonia occasionally appeared in the Prague Basin, which was located in the temperate zone at the northern margin of peri-Gondwana. The distribution pattern of phragmoceratids suggests that immigration into the Prague Basin occurred in three stages: (1) first appeared stray immigrants (or occasional visitors) from warmer seas, this stage of immigration reflecting activation of sea currents after the early Silurian widespread anoxia in peri-Gondwana (latest Llandovery-early Wenlock); (2) appearance of small endemic palaeo-populations of migrants (with evidence of local hatching of phragmocerids) that persisted only briefly during the early Homerian and early Gorstian low stands; (3) stable palaeo-populations appeared in the Early Ludfordian, with occurrence of endemic taxa related to the forms known from Baltica-Avalonia, suggesting stable conditions for nautiloid evolution. The Middle Ludfordian Kozlowskii Event caused the extinction of the last phragmocerid taxa in the Prague Basin as elsewhere. Nautiloid immigration to the Prague Basin (Perunica microplate) indicates that Perunica, in contrast to peri-Gondwanan areas, was within reach of the South Tropical Current since the latest Llandovery. Many other nautiloid families show a similar migration pattern although timing of the immigrations do not necessarily correlate. Thus the nautiloids provide useful data for palaeobiogeographic and climate reconstruction, such analysis can be made precise by comparison of nautiloid clades. - Key words: Silurian, Nautiloidea, Phragmoceras, migration, palaeoecology, peri-Gondwana, Perunica, Prague Basin.
\end{abstract}

MANDA, Š. 2008. Palaeoecology and palaeogeographic relations of the Silurian phragmoceratids (Nautiloidea, Cephalopoda) of the Prague Basin (Bohemia). Bulletin of Geosciences 83(1), 39-62. Czech Geological Survey, Prague. ISSN 1214-1119. Manuscript received November 7, 2007; accepted in revised form February 26, 2008, issued March 31,2008

Štěpán Manda, Czech Geological Survey, P.O.B. 85, Praha 011, 118 21, Czech Republic; stepan.manda@geology.cz.

A rich Silurian cephalopod fauna in the Prague Basin consisting of several hundreds of taxa has been known since Barrande's famous work (1865-1877). Here, cephalopods became abundant during the Wenlock as the successions of the Prague Basin changed from anoxic shales to calcareous shales and limestones. Therefore the majority of cephalopods that were described came from the Ludlow and Př́idolí cephalopod limestones (Fig. 1). "Orthocerids" with longicone shells predominate whereas more diverse forms of nautiloids (oncocerids, discosorids, barrandeocerids and tarphycerids) rarely occur. The distribution pattern of these nautiloids is poorly known as the majority of them were collected during Barrande's time, and there are only a few examples that may facilitate a case study of nautiloid distribution patterns; namely tarphycerids (Turek 1976, Stridsberg \& Turek 1997) and phragmoceratids. Amongst these taxa, the fossil record of phragmoceratids seems to be the best known in terms of biostratigraphic controls.

The Silurian family Phragmoceratidae Miller, 1877 (i.e. phragmoceratids) consists of two genera: Phragmoceras Broderip, 1839 (in Murchison 1839) and Tubiferoceras Hedström, 1917 (Discosorida Flower, 1940). Phragmoceratids possess a cyrtoconic or rarely orthoconic 


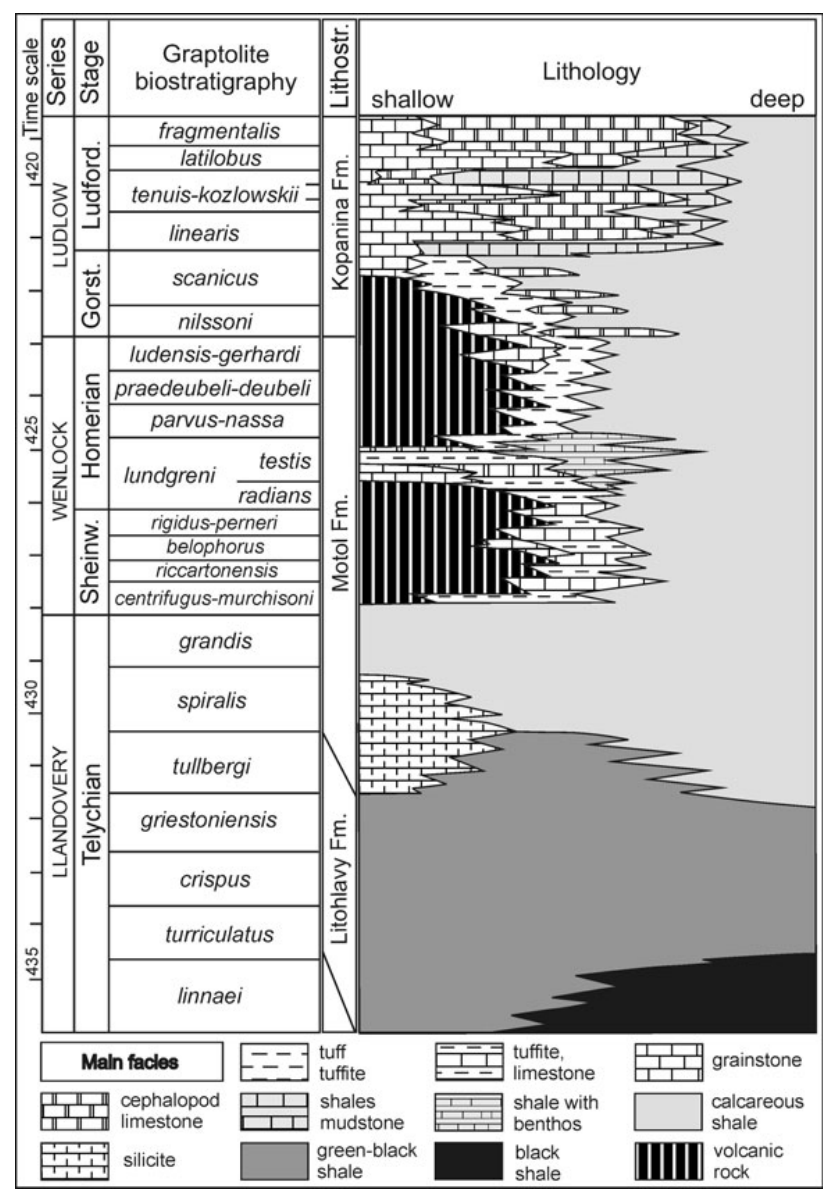

Figure 1. Llandovery, Wenlock and Ludlow stratigraphy and lithostratigraphy of the Prague Basin (adapted after Kř́̌ž 1991, 1992).

or coiled breviconic endogastric shell, with a more or less modified T-shaped contracted aperture. The siphuncle has broadly expanded and thick connecting rings (Flower \& Teichert 1957, Dzik 1984). Phragmoceras represented a characteristic component of Silurian nautiloid faunas, appearing just after the beginning of the Silurian boundary and survived into the middle Ludfordian of the Ludlow Series. Several species have been described from Gotland, Estonia, Podolia in Ukraine, North Ural, Siberia, Severnaya Zemlya, Inner Mongolia, Tian Shan, Illinois, Indiana, New York, Ohio, Ontario, Quebec, Wisconsin, Scotland, Wales and the Welsh Borderland, Ireland, Sardinia and Bohemia (for summary see Manda 2007). The genus Tubiferoceras Hedström, 1917 ranges from the middle Llandovery to the Wenlock, with a few species known from Gotland, Scotland, Indiana, Wisconsin, Siberia, and Bohemia (see Manda 2007).

Phragmoceratids inhabited mainly tropical carbonate platforms of Baltica and Laurentia. Their occurrence in shallow carbonate platforms close to the reefs should be compared with the distribution pattern and ecologic requirements of the living Nautilus Linné, 1758 representing a model animal in palaeobiologic studies of fossil nautiloids. Nevertheless, diverse nautiloids including phragmoceratids also occurred in the Prague Basin (Perunica), located during the Silurian in the temperate zone. A few nautiloids, including phragmoceratids also occurred in other peri-Gondwanan terranes, including some located in the cool zone.

With the exception of the Ludfordian Phragmoceras broderipi, which is represented in many collections and also commonly figured as an example of the genus (e.g., Koken 1896, Gürich 1908, Basse 1952, Prantl 1952, Dzik 1984), in the Prague Basin, phragmoceratids usually occur rarely in thin horizons at a few localities. Phragmoceras broderipi is very common at certain levels at some of Barrande's localities (e.g., Kovářovic mez Section; Lochkov, App. loc. 10) and represents one of most common nautiloids in the Prague Basin.

The present study deals with palaeoecology, mode of life and geographic and stratigraphic distribution patterns of phragmoceratids in the Prague Basin (Perunica) and peri-Gondwana. The mode of life of nautiloids with constricted aperture remains poorly understood. New material collected during the last decade makes possible a new evaluation of earlier published interpretations of the palaeoecology. The distribution pattern of phragmoceratids is compared with other nautiloid families as well as recent Nautilus. The other questions addressed in this paper are: How did colonisation of the submarine highs by nautiloid immigrants proceed after the early $\mathrm{Si}$ lurian anoxic episode in the Perunica and peri-Gondwana? What factors invoked the survival and further evolution of the nautiloid immigrants of Perunica and peri-Gondwana?

\section{Material}

Barrande's collection is housed in the National Museum, Prague (prefix L). Other material is deposited in collections of the Czech Geological Survey, Prague. Material collected by the author is deposited in the author's collection at the Czech Geological Survey, Prague (prefix SM). An index of mentioned localities is given in the Appendix and their geographic positions are shown in Fig. 2.

\section{Taxonomic remarks: What is meant by "nautiloid"?}

In the 1950, Flower \& Kummel proposed a classification of cephalopods in which the subclass Nautiloidea Agassiz, 1847 included the orders Ellesmeroceratida Flower, 1950, Orthocerida Kuhn, 1940, Discosorida Flower, 1940, Oncocerida Flower, 1950, Barrandeocerida Flo- 


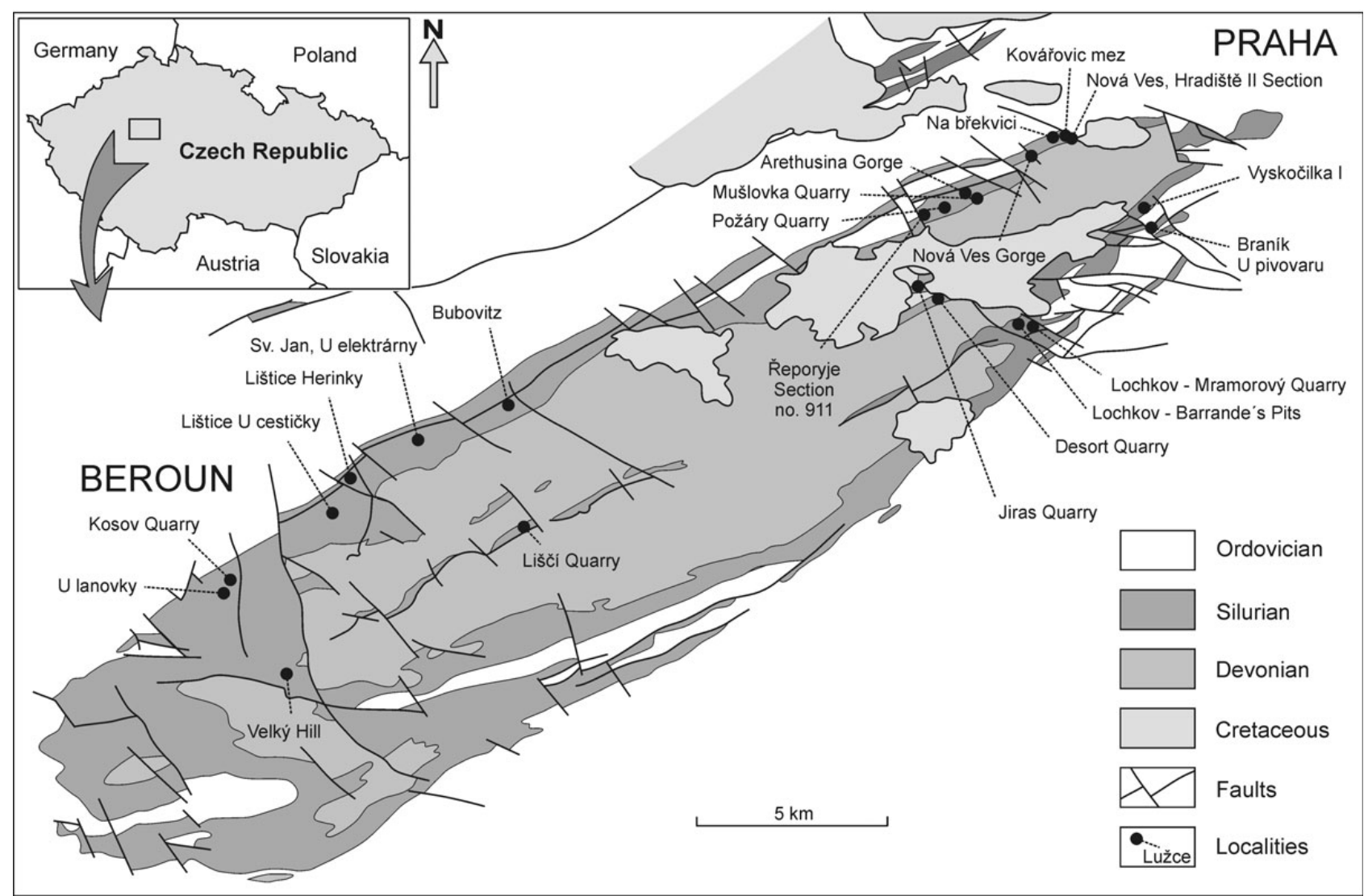

Figure 2. Distribution of Silurian rocks in the Prague Basin and the location of the sections discussed in the text (adapted after Kříz 1991 , 1992 and Röhlich 2007).

wer, 1950, Tarphycerida Flower, 1950 and Nautilida Agassiz, 1847. This classification was generally adopted in the Osnovy Paleontologyi (Ruzhencev 1962) as well as in the Treatise on Invertebrate Paleontology (Moore 1964) and has been commonly used until now. Herein, author follows Teichert's (1988) classification, in which subclass Nautiloidea contains orders Discosorida, Oncocerida, Barrandeocerida, Tarphycerida and Nautilida. Whilst the former "Nautiloidea" grouped together cephalopods with different life strategies, the Nautiloidea as defined by Teichert (1988) contains cephalopods with similar general morphologies, embryonic development, life cycle and ecologic requirements comparable with Recent Nautilus, thereby providing the term 'nautiloids' with a useful sense in relation to palaeoecologic and palaeogeographic studies.

\section{Phragmoceratids from the Prague Basin}

Up to now, 14 species of Phragmoceras were described from the Prague Basin and each of them is briefly introduced below. The history of investigations on the Bohemian phragmoceratids was summarised by Manda (2007).
Subclass Nautiloidea Agassiz, 1847

Order Discosorida Flower, 1950 (in Flower \& Kummel 1950)

Family Phragmoceratidae Miller, 1877

\section{Genus Tubiferoceras Hedström, 1917}

Tubiferoceras proboscoideum Hedström, 1917. - The lectotype from the early Silurian strata of Gotland was designated by Foerste (1926) from a figure of Hedström (1917, pl. 1, figs 4, 5-2). Two specimens were described by Manda (2007) from the early Wenlock strata of the Prague Ba$\sin$.

\section{Phragmoceras Broderip, 1839 (in Murchison 1839)}

Phragmoceras acuminatum Hedström, 1917. - A lectotype was designated by Kiselev (1986) from a figure of Hedström (1917, pl. 10, figs 5, 6), Wenlock, Visby Formation, Larbo Section, Gotland. This taxon also occurs in the late Wenlock of the Prague Basin (Manda 2007) and probably the early Wenlock of Podolia, Ukraine (Kiselev et al. 1987). 
Phragmoceras biimpresum (Barrande, 1865). - Barrande (1865, pl. 60, figs 1-4) figured two specimens from Bubovitz e1 locality (App. loc. 3) from brachiopod packstones of early Homerian age.

Phragmoceras labiosum Barrande, 1865. - This taxon is based on several specimens from Hinter Kopanina e2 and Konieprus e2 (App. locs 5, 7) (Barrande 1865, pl. 50, figs 1-6, pp. 218, 219). An additional specimen was found in the early Ludfordian U lanovky Section (App. loc. 23). Gnoli (1993) reported a single specimen of Phragmoceras labiosum from the Ludlow of Sardinia. Phragmoceras labiosum is closely related to Phragmoceras retortum Hedström, 1917 from the Ludlow of Gotland (Holland \& Stridsberg 2004).

Phragmoceras longum Barrande, 1865. - This species was erected for several specimens from Lochkov e2 and Hinter Kopanina e2 (App. locs 5, 14) (Barrande 1865, pp. 213, 214, pl. 59, figs 1-4). Additional new, mostly fragmentary, specimens were collected from the early Ludfordian cephalopod limestone at Desort Quarry, Zadní Kopanina (App. loc. 6). Phragmoceras longum is closely related to Phragmoceras inflexum Hedström, 1917 from Gotland. Both species have a distinctive, laterally compressed cyrtoconic shell.

Phragmoceras imbricatum Barrande, 1865. - A lectotype was designated by Holland \& Stridsberg (2004) based on the specimen figured by Barrande (1865, pl. 46, figs 1-4). The type locality is Vyskočilka e2 near Prague (App. loc. 26). The lectotype probably came from the cephalopod limestone beds of the early L. scanicus Zone (Manda \& Kř́iž 2007). Most of specimens figured by Barrande were found in the cephalopod limestones of the early Ludlow Series, Butovitz e1 locality (Butovice Na břekvici Section No. 584; App. loc. 4). Some additional specimens were found during recent field studies at other locations in the early Ludlow Series (řeporyje Section No. 911; Kosov Quarry, "new quarry”, SW wall; Liščí Quarry; App. locs 21, 8, 11). Phragmoceras imbricatum was also recently re-described by Holland \& Stridsberg (2004). Outside the Prague Basin, Phragmoceras imbricatum occurs in the Wenlock and early Ludlow rocks of Britain and Gotland (Holland \& Stridsberg 2004) and has been recovered from Polish erratic boulders (Noetling 1884).

Kiselev (1984) assigned specimens of Phragmoceras imbricatum having an open aperture (Barrande 1866, pl. 46, figs 1-12) to Protophragmoceras butovitcenze Kiselev, 1984, the lectotype of which came from the early Ludlow Series of the North Urals (Kiselev 1984, p. 52, pl. 10, fig. 1, pl. 11, fig. 1) but Kisselev's illustration does not provide sufficient information to evaluate if the specimens from the Prague Basin and the Urals are really conspecific. However, the Prague Basin specimens, considered to be Protophragmoceras butovitcenze by Kiselev (1984), represent an early stage of Phragmoceras imbricatum, as already noted correctly by Barrande (1866).

Phragmoceras sigmoideum Hedström, 1917. - The lectotype was designated by Kiselev (1984) from a figure by Hedström (1917, pl. 17, fig. 1) from the Wenlock Visby Formation, Larbro, Storugns, Gotland (Hedström 1917). The species also occurs outside the Wenlock of Gotland, in the early Ludlow of the North Urals (Kiselev 1984) and late Wenlock of the Prague Basin (Manda 2007).

Phragmoceras munthei Hedström, 1917. - The lectotype was designated by Holland \& Stridsberg (2004) based on the specimen figured by Hedström (1917, pl. 25, figs 1-3) from the early Wenlock Visby Formation of Visby, Gotland. Phragmoceras munthei also occurs in the late Llandovery and Wenlock of Gotland (Holland \& Stridsberg 2004), the Wenlock of Estonia (Kiselev et al. 1990), the latest Llandovery and earlier Wenlock of the Prague Basin, and probably the latest Llandovery of Ireland (Manda 2007).

Phragmoceras cf. undulatum Hedström, 1917. - A single body chamber similar to that of Phragmoceras undulatum (Wenlock of Gotland) was recently described from the Prague Basin by Manda (2007).

Phragmoceras cf. venticosum Sowerby, 1839 in Murchison (1839). - Three specimens similar to Phragmoceras venticosum were described by Manda (2007) from the late Wenlock of the Prague Basin. Phragmoceras venticosum occurs in the Wenlock and early Ludlow of Wales and the Welsh Borderland (see Holland \& Stridsberg 2004).

Phragmoceras koneprusensis Manda, 2007. - This species was described based on a single shell from the early Ludfordian strata of the Velký Hill Section (App. loc. 24).

Whereas the above-mentioned Bohemian taxa represent rather distantly related species of Phragmoceras, the Ludfordian Phragmoceras broderipi sublaeve, Phragmoceras broderipi broderipi, and Phragmoceras beaumonti are closely related and are considered to belong a single evolutionary lineage of phragmoceratids in the Prague Basin (Fig. 3). These taxa are known only from the Prague Basin. Taxa similar to the Ludfordian Phragmoceras broderipi occur in Wenlock and Ludlow strata of Gotland (Holland \& Stridsberg 2004).

Phragmoceras beaumonti (Barrande, 1865). - The lectotype designated by Flower \& Teichert (1957) is the specimen figured by Barrande (1865, pl. 165, figs 1-5) as Cyrto- 

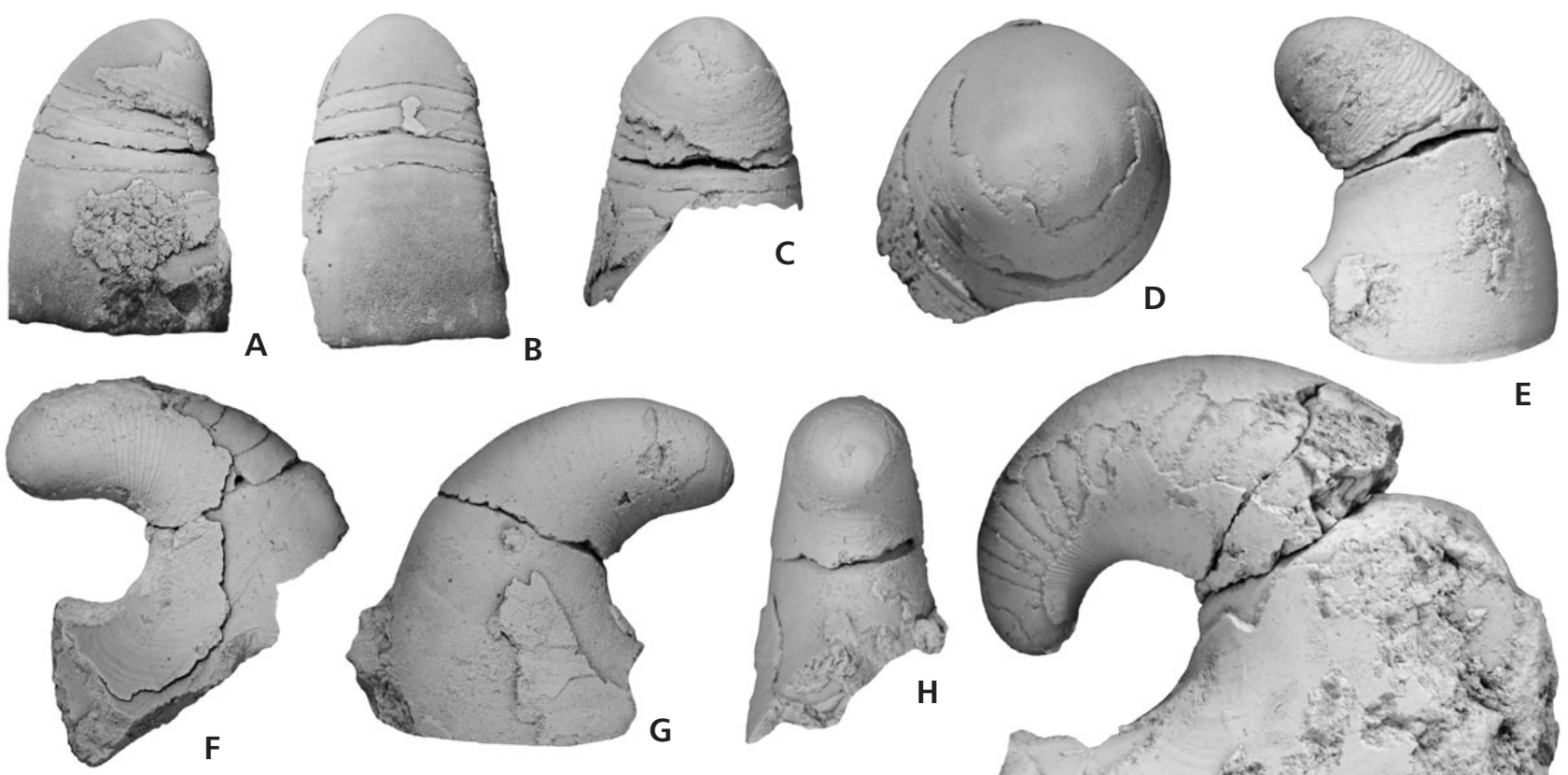

E
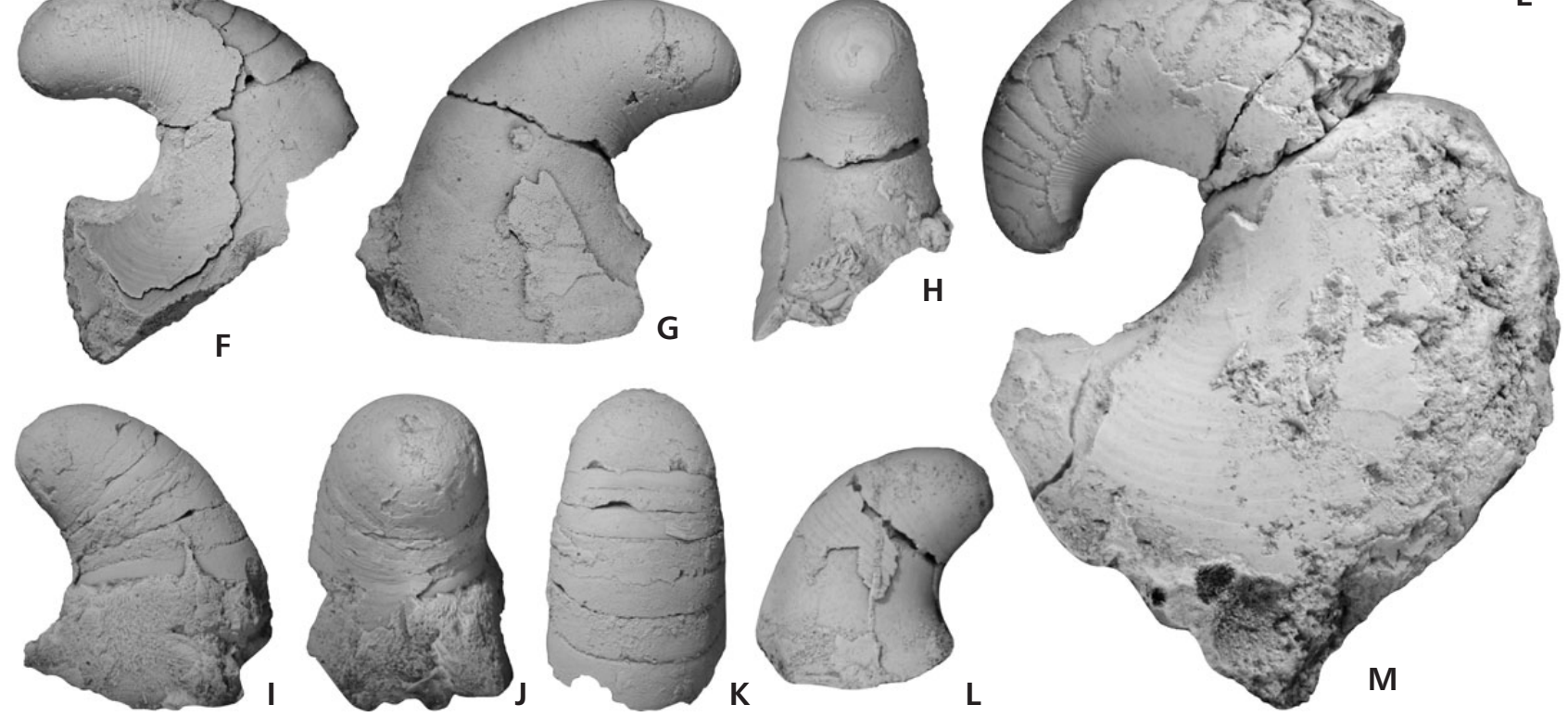

Figure 3. Embryonic chambers of phragmoceratids, early post-hatching specimens (A-L). • A-D - Phragmoceras cf. ventricosum Sowerby, 1839, Lištice U cestičky Section No. 759, Wenlock, Homerian, T. testis Zone; CGS SM 74; lateral (A), dorsal (B), ventral (C), × 2 , apical view (D), × 3. - E - Phragmoceras beaumonti (Barrande, 1866), Mramorový Quarry Section no. 357, Ludlow, Ludfordian, uppermost N. kozlowskii Zone; CGS SM 99; lateral view, $\times 1.4$ • F - Phragmoceras beaumonti (Barrande, 1866), Nová Ves, Hradiště II Section, bed No. 9; Ludlow, Ludfordian, N. kozlowskii Zone; CGS SM 73; lateral view, × 1.1. • G, H - Phragmoceras broderipi sublaeve Barrande, 1865, Velký Hill Section; Ludlow, Ludfordian, S. linearis Zone; CGS SM 98; lateral (G) and ventral $(\mathrm{H})$ view, $\times 1.5$. • I-K - Phragmoceras broderipi broderipi Barrande, 1865, Kovárovic mez Section; Ludlow, Ludfordian, S. inexpectatus Zone; CGS SM 55; lateral (I), ventral (J) and dorsal (K) view, × 1.9. • L - Phragmoceras beaumonti (Barrande, 1866), Nová Ves, Hradiště II Section; Ludlow, Ludfordian, N. kozlowskii Zone; CGS SM 62; lateral view, × 1.8. • M - Phragmoceras beaumonti (Barrande, 1866), Nová Ves, Hradiště II Section; Ludlow, Ludfordian, N. kozlowskii Zone; CGS SM 61; lateral view, × 1.3.

ceras beaumonti (Lochkov e2; App. loc. 14). Flower \& Teichert (1957) regarded Cyrtoceras beaumonti to belong to the Protophragmoceras Hyatt, 1900. The latter genus differs from Phragmoceras in its slender cyrtocone shell and thinner siphonal tube. Dzik (1984) considered Cyrtoceras beaumonti to represent a juvenile stage of Phragmoceras broderipi. However, Phragmoceras beaumonti is a distinct species, which did not close its aperture in the adult stage and also has a smaller more coiled shell than Phragmoceras broderipi broderipi. New material of Phragmoceras beaumonti was collected recently from many localities in the late early Ludfordian strata of the Prague Basin.

Phragmoceras broderipi (Barrande, 1865). - Phragmoceras broderipi consists of two subspecies: Phragmoceras broderipi sublaeve (Barrande 1865, pl. 57, fig. 7, pl. 98, figs 1-4) and Phragmoceras broderipi broderipi (Barrande 1865 , pls 56-58, 99). The subspecies differ mainly in sculpture. The first has a smooth shell or gently developed growth lines and the latter shows prominent growth lines sometimes forming irregular walls. New material of both subspecies was obtained recently from many sections in the early Ludfordian strata of the Prague Basin.

\section{Ontogeny and mode of life of the Phragmoceras}

The contracted aperture of adult phragmoceratids may be suggestive of a microphagous habit with reduced arms, as assumed by Abel (1916). Prell (1921) compared phragmoceratids with the Recent gastropod Cypraea and suggested 
that the body of Phragmoceras could flow out of the "extremely" restricted aperture. Further, he concluded that swimming using the hyponome was impossible in phragmoceratids and so assumed a life as bottom dwellers. Pia (1923) agreed with the proposal of a microphagous habit, but postulated active swimming behaviour. Flower (1957) considered that active swimming was too difficult and regarded phragmoceratids as benthic crawlers.

Holland (1984, p. 157), in his summary of Silurian cephalopod palaeoecology, agreed with Abel (1916) when he wrote: "It is difficult to see such a form other than as microphagous." Hewitt \& Watkins (1980, p. 106) even suggested that phragmoceratids "might conceivably have had vegetarian habits". Westermann (1998, p. 281, fig. 20.13) made a reconstruction of Phragmoceras and suggested that the hyponome was at the height of the dynamic centre and thus Phragmoceras could be seen as a moderately good forward swimmer above a shallow substrate after brachiopod prey. Westermann (1998, p. 292) also commented on the lamellar subdivision of the siphuncle, indicating that it was "presumably for improved buoyancy regulation, permitting either for vertical migrations or hiding on the sea during storms". Whilst agreeing that phragmoceratids were active swimmers, Holland \& Stridsberg (2004) assumed that the downward orientation of the apertural opening limited the ability of phragmoceratids to orient themselves. Nevertheless, Recent Nautilus is able to orient itself using not only visual cues, but also the use of chemical signals, and a similar mode of orientation can be assumed for fossil nautiloids (Basil et al. 2000).

Consideration of the deficiencies in the palaeoecologic interpretation of Phragmoceras should focus on the late ontogenetic stage where a contracted aperture is present. However, the contracted aperture only appeared as a modification of the mature animal at the end of shell growth. Phragmoceratids spent a major proportion of their life with a brevicone shell and open aperture.

\section{Embryonic stage and hatching time of phragmoceratids}

The embryonic shell of Phragmoceras is cup-like and slightly curved on the ventral side with an elliptical cicatrix. The diameter of the first chamber varies from $6.3 \mathrm{~mm}$ up to $10 \mathrm{~mm}$ with its height ranging from $5.6 \mathrm{~mm}$ up to $6.9 \mathrm{~mm}$. The distance between the following septa usually continually increases. In some specimens, up to two shallow camerae are developed (Fig. 3J-L). Growth lines appear on the embryonic chamber around the field of the cicatrix or at the first camera, and their distance usually increases slightly but continuously (Barrande 1867, Hedström 1917, Manda 2007; see Fig. 3).

Due to the absence of a distinctive change in morphol- ogy, the recognition of the hatching time in Phragmoceras (as well as other early Palaeozoic nautiloids) is uncertain. Hatching time of nautilids is clearly marked by a nepionic constriction (i.e., constriction of the shell) and is usually accompanied by changes in ornament and distance between septa (e.g., Teichert 1964, Ward 1987, Chirat \& Rioult 1998). Changes in ornament and spacing of septa are concentrated between the embryonic chamber and the $3^{\text {rd }}$ septum in phragmoceratids (Fig. 3). Turek (2007) observed a similar early ontogenetic pattern in the Early Devonian oncocerids Ptenoceras proximum Barrande, 1865 and Hercoceras mirum Barrande, 1865. Thus, the hatching size of the Silurian phragmoceratid and Devonian hercoceratids was rather lower than that of post-Triassic nautilids (see Chirat \& Rioult 1998).

A hatching site can be identified in the fossil record by the presence of specimens that died shortly after hatching (i.e., as a consequence of a mass kill), because the embryonic shell is present throughout life. The majority of embryonic portions are found attached to part of the adult phragmocone, which was broken off from the rest of the shell during post-mortem processes, and thus a deposit with such remains does not indicate hatching place.

The Silurian early post-hatching nautiloids occur together where the density of adult-populations was at their greatest, e.g., Phragmoceras imbricatum, Butovice Na břekvici Section No. 584 (see Barrande 1866, pl. 46; App. Loc. 4). At the margins of these populations, the early post-hatching stage is missing, i.e., in deeper water environments (see Fig. 13). Silurian phragmoceratids hatched in relatively shallow environments below wave-base. A similar distribution pattern has been observed for several Silurian oncocerids (unpublished data). Thus the Silurian nautiloids do not exhibit the segregation of adult and early post-hatching individuals described in post-Triassic taxa (Ward 1987, Chirat \& Rioult 1998).

\section{Neanic and early ephebic stages of phragmoceratids with open aperture}

The majority of phragmoceratids have a relatively rapidly expanding and endogastric shell (Figs 4, 5). The siphuncle is positioned on the shorter ventral side. With increasing diameter, the width of siphonal tube increases with a slight allometry. The cylindrical connecting rings are relatively thick. The body-chamber is usually relatively long relative to the phragmocone. The hyponomic sinus is generally shallow and relatively narrow. Stridsberg (1985) pointed out that an endogastric breviconic shell is more suitable for swimming than an exogastric. Silurian brevicones with a slightly curved shell are usually endogastric. In contrast, brevicones with cyrtoconic shell are mostly exogastric. Phragmoceras is virtually the only $\mathrm{Si}$ - 


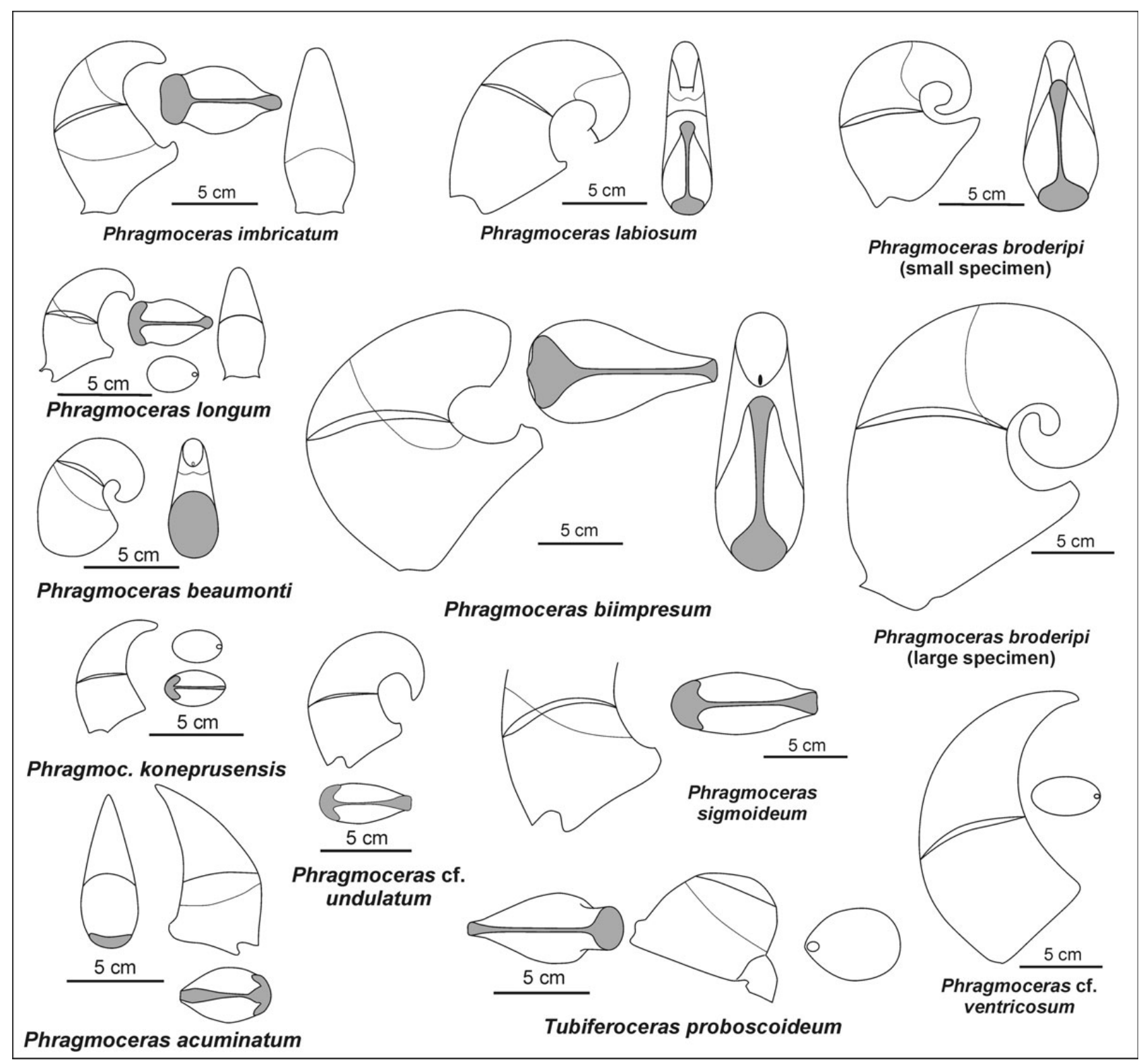

Figure 4. General morphology of Silurian phragmoceratids from the Prague Basin. Diagram showing presumed life position.

lurian nautiloid with an endogastric and cyrtoconic shell. Constructional constraints might possibly explain the relative rarity of endogastric cyrtoconic shells because the siphuncule is placed on the shorter side and thus provides a lower effective surface. The rapidly expanding siphuncle in phragmoceratids probably balanced this constructional handicap. Early phragmoceratids possessing an open aperture probably lived close to the bottom as nectobenthic predators.

An interesting feature is that the height and width of the aperture was much larger just in front of the aperture closure than after. This suggests that the head and arms were dorsally placed (i.e. in around the broad, shallow saddle of the aperture) and did not fill the whole aperture as in nautilids or tarphycerids (Fig. 5). This conclusion fits well with observations made by Kröger (2007) on the earliest Ordovician ellesmeroceratids; he suggested that the dorsally placed (in conventional terminology) head-arm complex and associated multiple-paired retractor muscles represent the basal body plan for nautiloids. Recently, Shigeno et al. (2008) reported embryological evidence for the morphological development of the head complex of the unique assembly of multiple archetypal molluscan body parts in Nautilus. The commonly developed constriction of the aperture of some oncocerids and discosorids should provide additional evidence for a dorsally placed head-arm complex because in such cases the constriction of the aperture limited the head-arm complex less than was previously thought. 


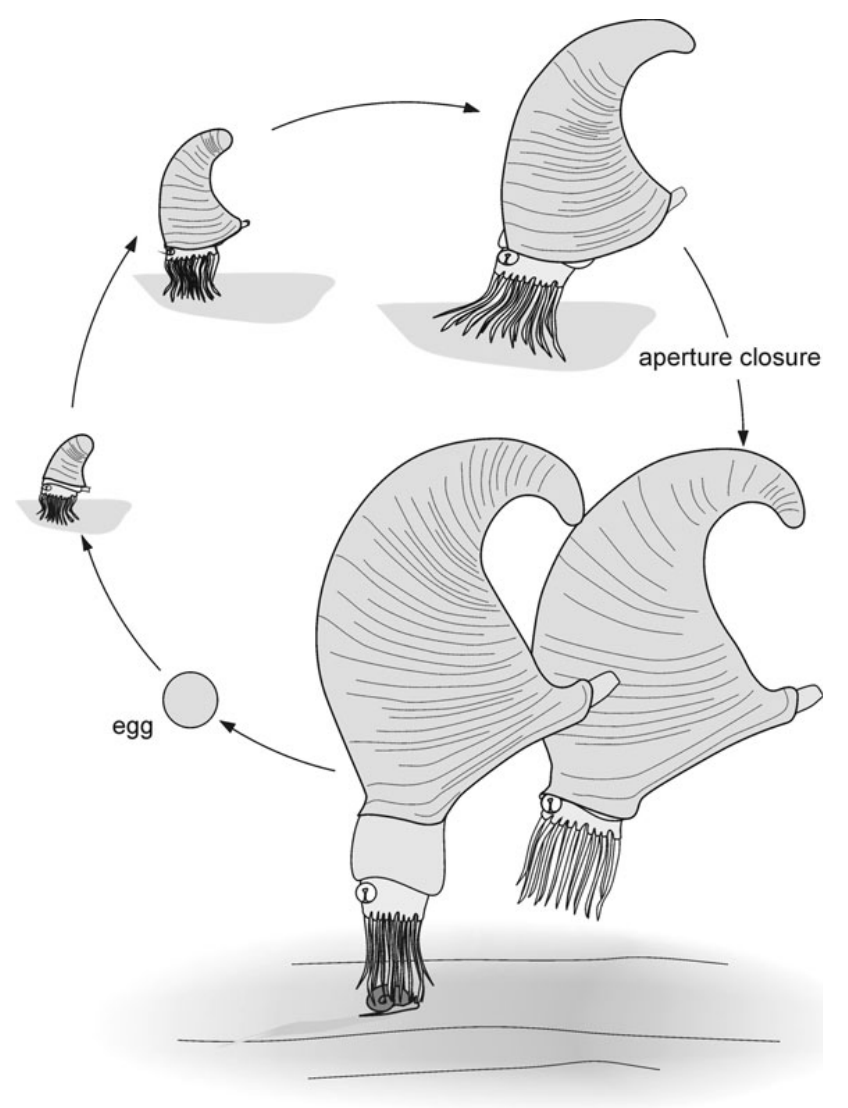

Figure 5. General morphology, ontogeny and mode of life of Phragmoceras imbricatum. Diagram shows change in mode of life during aperture closure in the late ephebic stage.

\section{Late ephebic stage of phragmoceratids with contracted aperture}

The constriction of the aperture in Phragmoceras corresponds to the cessation of shell growth in the long axis. The high frequency of growth lines at the constriction of the body-chamber indicate a decrease in shell growth rate, as reported in brevicone oncocerids (Stridsberg 1985). The shape of the contracted aperture in phragmoceratids is variable. The apertural opening faces downward or is dorsally oriented. The shape is also variable: circular to elliptical, sometimes with lobes developed or surrounded by a collar (e.g., Phragmoceras imbricatum, Figs 4, 5). The hyponomic sinus is narrow and is terminated by a protruding hyponomic opening. A few species (e.g., Phragmoceras labiosum, Fig. 4) have a T-shaped contracted aperture with a narrow apertural opening. One or two very shallow camerae may have been precipitated after the closure of the aperture. In addition, after apertural closure shell growth continued around the apertural opening and a more or less protruding collar developed. The highly variable thickness of the shell at the aperture and anterior part of the body chamber suggests that the shell continually thickened after apertural closure, e.g., in Phragmoceras broderipi the shell thickness at the hyponomic opening varies from $2 \mathrm{~mm}$ to $9 \mathrm{~mm}$.

The contraction of the aperture probably improved swimming as well as passive floating by providing a more hydrodynamically efficient shell-shape with a fixed and protruding hyponomic opening supporting the hyponome. This idea supports the phragmocerid distribution pattern; the specimens with an open aperture were restricted to shallower areas whereas specimens with a contracted aperture were widely distributed across the slope, even if the size of their shells differs only slightly. The presence of a similar distribution pattern in other nautiloids with contracted aperture cannot be tested because those early stages with open aperture are missing from the fossil record, i.e., those cephalopods had a very low mortality before the stage during which the aperture became constricted (e.g., Hemiphragmoceratidae Foerste, 1936).

The contracted aperture and collar lining the apertural opening probably also improved protection of the soft body against predators (Teichert 1964, Stridsberg 1985). On the other hand, the constriction of the aperture limited the size of the buccal mass and thus complicated food capture. There appears to be adaptive conflict: protection/improved buoyancy versus sufficient food intake.

\section{Muscle scars of Phragmoceras: Implications for the mode of life of an ephebic phragmocerid possessing a contracted aperture}

A further possible function of the contracted aperture might be the support of the soft body within the shell (Teichert 1964). Nevertheless, phragmoceratid shells commonly exhibit well-developed muscle scars. Why then are prominent retractor muscles developed in combination with a constricted aperture? The frequent preservation of muscle scars in phragmoceratids can be attributed to their relatively thick shells, because muscle scars are more frequently preserved in thick-shelled molluscs (e.g., Stanley 1970). However, some Silurian nautiloids with a similar shell shape and shell thickness to those of phragmoceratids exhibit the preservation of muscle scars less frequently, e.g., Rizoceras Hyatt, 1884 and Protophragmoceras Hyatt, 1900 with a breviconic shell and open aperture, or even Octameroceras Hyatt, 1900 with a breviconic shell and contracted aperture. Thus the frequent preservation of muscle scars in phragmoceratids reflects rather well-developed muscles. Well-preserved muscle scars were found in three species as described below.

The annular elevation of Phragmoceras imbricatum (Fig. 6C, D, G) is relatively low, $3 \mathrm{~mm}$ wide with elliptical longitudinally elongated muscle scars. On the ventral side, the annular elevation is reduced in width and a pair of me- 


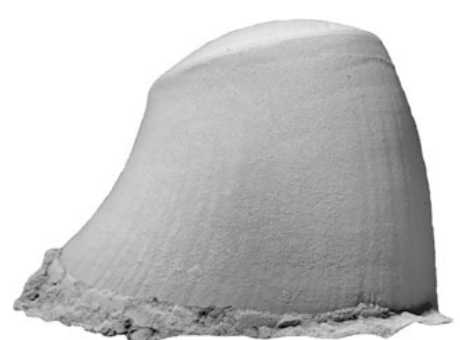

A

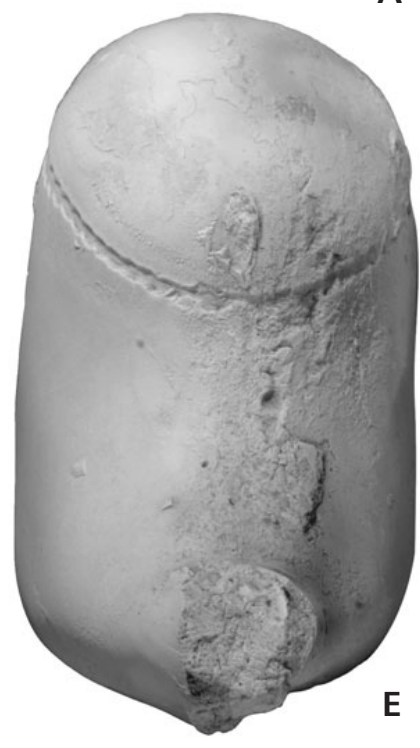

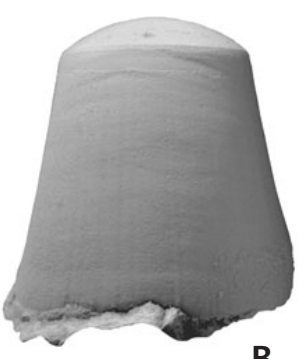

B

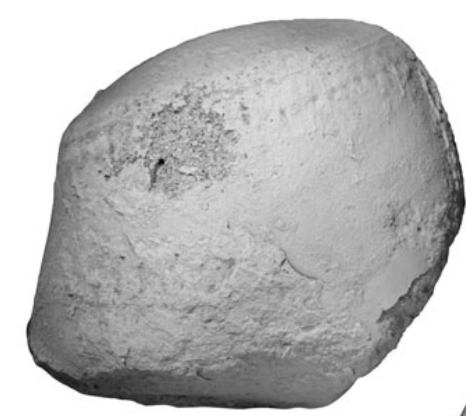

C
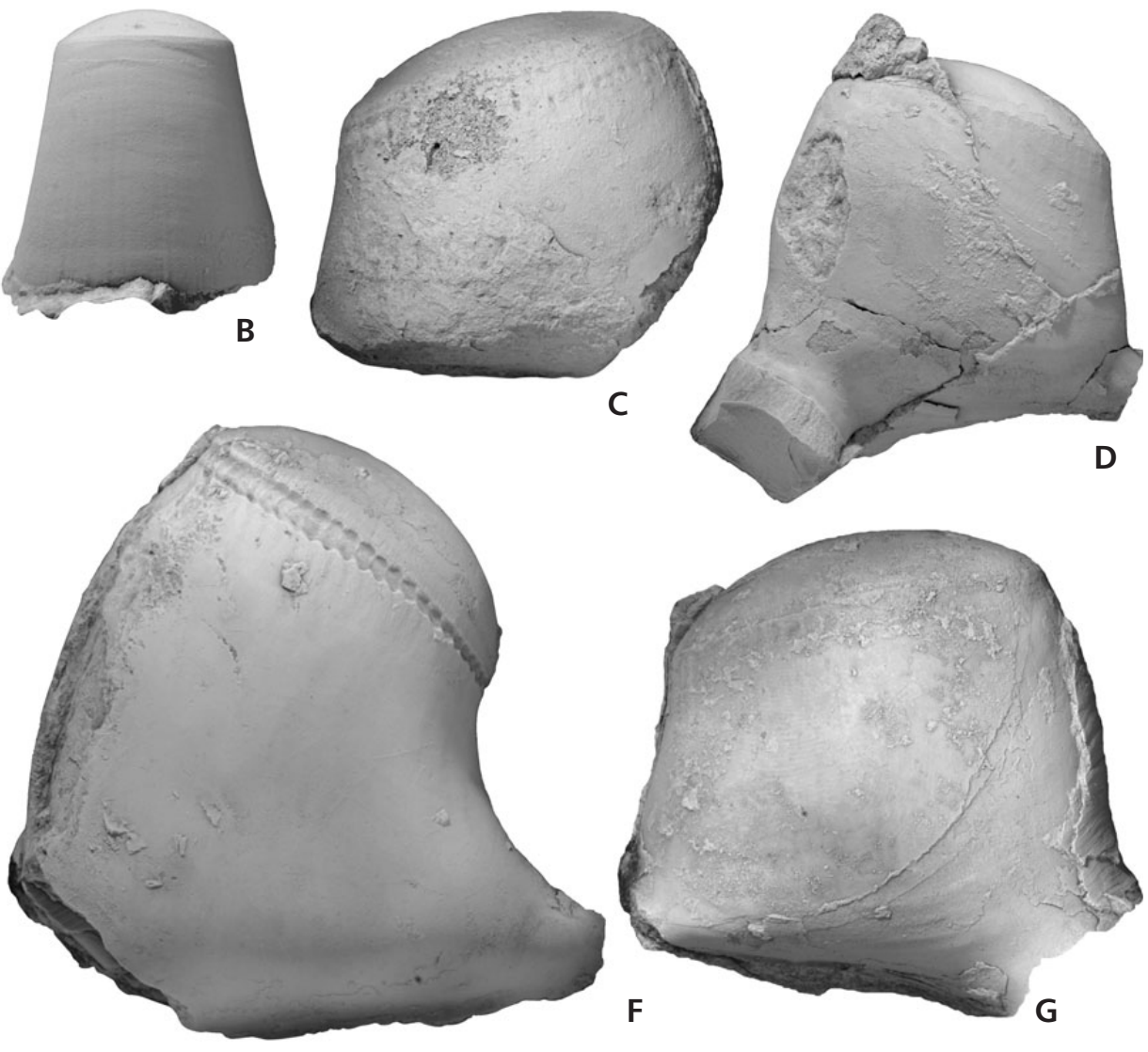

D

Figure 6. Muscle scars in Phragmoceras. • A, B - Phragmoceras acuminatum Hedström, 1917, Arethusina Gorge Section No. 687; Wenlock, Homerian, T. testis Zone; leg. J. Kř́ž; CGS SM 78 lateral (A) and dorsal (B) view, × 1.8. • C - Phragmoceras imbricatum Barrande, 1865, Kosov Quarry, "new quarry", SW wall; Ludlow, Gorstian, S. chimaera Zone; CGS SM 57; lateral view, × 0.8. • D - Phragmoceras imbricatum Barrande, 1865 , Butovice Na břekvici Section No. 584; Ludlow, Gorstian, C. colonus Zone; Barrande's collection NM L40299; lateral view, $\times 0.7$. $\bullet$ E, F - Phragmoceras broderipi broderipi Barrande, 1865; Kosov Quarry, "old quarry"; Ludlow, Ludfordian, S. inexpectatus Zone; CGS SM 70; ventral (E) and lateral (F) view, × 0.8. - G - Phragmoceras imbricatum Barrande, 1865, Butovice Na břekvici Section No. 584; Ludlow, Gorstian, C. colonus Zone; leg. J. Kříž and R. Horný; CGS SM 92; lateral view, $\times 1$.

dially elongated muscle scars is developed (Fig. 8B, CGS SM 80). On the distal part of the last septum, imprints of the palliovisceral ligament may be seen. More or less straight, longitudinal ridges directed parallel to the apertural opening are developed below the annular elevation.

Specimens of Phragmoceras broderipi broderipi (Fig. 6E, I) possessing contracted apertures exhibit annular elevations that are segmented into 23 pairs of muscle scars. The width of the elevation increases from $2 \mathrm{~mm}$ on the ventral side to $5 \mathrm{~mm}$ on the lateral side; on the dorsal side, the width of the elevation decreases slightly again. The muscle scars close to the ventral side are trapezoidal in shape, whereas close to the dorsal side they are longitudinally elongated with a medial ridge. The ad-oral margin of the annular elevation is sinusoidal, whereas the opposite margin is formed in asymmetrical waves. The imprint of the palliovisceral ligament is preserved on the terminal part of the last septum. A zone with longitudinal and slightly ventrally curved ridges is developed below the annular elevation. The width of the zone increases from $5 \mathrm{~mm}$ on the ventral side up to $12 \mathrm{~mm}$ on the dorsal side of the specimen. The width of the zone with longitudinal ridges of the specimen figured by Barrande (1865) on pl. 99 as fig. 1, increases from $12 \mathrm{~mm}$ on the ventral side up to $18 \mathrm{~mm}$ on the dorsal side and the anterior termination forms a fine elevation.

The muscle scars described above occur in specimens with a contracted aperture. Early stages with open aperture exhibit a simple narrow annular elevation. For example, the early stage of Phragmoceras acuminatum with an open aperture (Fig. 6A, B) shows a $1 \mathrm{~mm}$-wide annular elevation parallel with the suture. The width of the annular elevation decreases slightly on the ventral side. Gently longitudinal ridges that terminate close to the aperture are developed below the elevation. The distance between the ridges is about $1 \mathrm{~mm}$, and dorsally this distance is doubled (Fig. 6B).

These serial muscle scars are shared by oncocerids and discosorids, and were grouped by Mutvei (1964) as Oncoceratomorphs. Between seven and 25 pairs of muscle attachment scars can be present, with the ventral pair being the largest (Kröger \& Mutvei 2005). Such a prominent and 

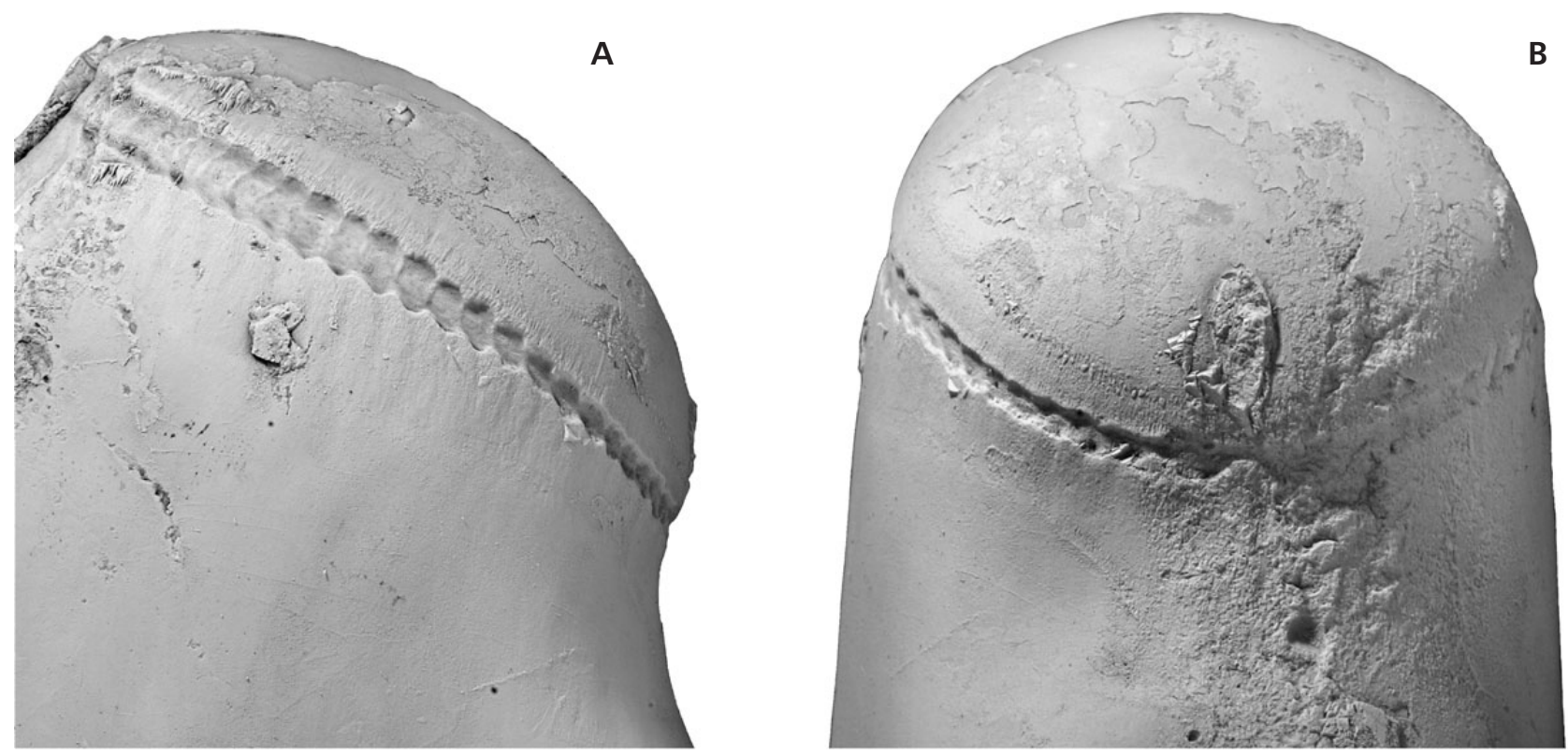

Figure 7. A, B - Phragmoceras broderipi broderipi Barrande, 1865 - detail of annular elevation; Kosov Quarry, "old quarry"; Ludlow, Ludfordian, S. inexpectatus Zone; CGS SM 70; lateral (A) and ventral (F) view, $\times 1.6$.

laterally elongated ventral muscle scar pair was described by Sweet (1959) from the late Ordovician Parryoceras euchari Sweet \& Miller, 1957 (Fig. 8A) belonging to the family Cyrtogomphoceratidae (from which the Phragmoceratidae are thought to have diverged in the Silurian, see Flower \& Teichert 1957). Phragmoceras is distinctive amongst discosorids in its reduced area $(P$. imbricatum) or even absence ( $P$. broderipi) of the ventral pair of differentiated muscle attachment scars (Fig. 8). In contrast, the width of the annular elevation and its segmentation increases on the lateral surfaces. The inferred reduction of the ventral pair of muscles in phragmoceratids suggests a high degree of evolutionary plasticity in the musculature driven by adaptive changes in the form of the shell.

The recognition of the imprints of the palliovisceral ligament as similar to those described in Recent Nautilus and post-Palaeozoic nautilids (Deecke 1913, Klug \& Lehmkuhl 2004) is notable.

The longitudinal ridges below the annular elevation in early-post hatching Phragmoceras acuminatum indicates the early segmentation of the muscles although this has not yet been exhibited by muscle attachment scars on the annular elevation. The longitudinal ridges correspond to the elongated muscle attachment scars on the annular elevation and are oriented toward the apertural opening. Following Mutvei (1964), the longitudinal ridges on the inner shell indicate a shallow mantle cavity on each side of the central foot. The segmentation of the annular elevation becomes distinctive as the aperture becomes constricted.

In comparing the morphologies of a shell with an open aperture and one with a contracted aperture, the first com- parison characterizes phragmoceratids as nectobenthic predators and the second as microphages, and so the question is raised as to whether such a change was possible during the ephebic stage? Is a microphagous habit really the only possible interpretation of phragmoceratids with a contracted aperture?

Phragmoceras beaumonti is a phragmocerid in which the constricted aperture is not developed, which may suggest that sexual maturity in phragmoceratids preceded the closure of the aperture. Thus the closure of the aperture may be considered to be a special adaptation to improve active swimming and protect the organs (i.e. a mature modification). Phragmoceratids with contracted apertures swam or floated in currents above the sea-floor searching for prey below. The prominent muscle attachment scars combined with the morphology of the apertural opening suggests that the head was normally protected within the shell, but during predation it could shoot out of the apertural opening by using the well-segmented muscles (Fig. 5). The wide siphuncle not only improved buoyancy regulation but probably also accelerated the vertical migration of phragmoceratids during food capture ( $c f$. Westermann 1998, see p. 49).

\section{Nature of fossil nautiloid assemblages}

Each study in the past dealing with cephalopod palaeoecology and distribution patterns started with a crucial question - How much are fossil cephalopod assemblages affected by long-term post-mortem drift of the cephalopod shells? Two contradictory approaches have been presen- 

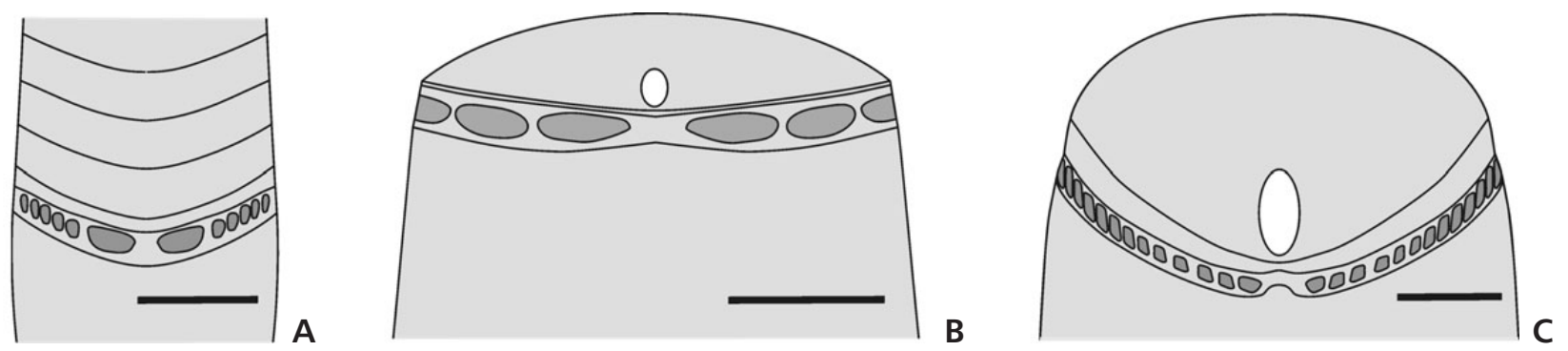

Figure 8. Idealized muscle scar shapes at Parryoceras euchari Sweet \& Miller, 1957 (A), Phragmoceras imbricatum Barrande, 1865 (B) and Phragmoceras broderipi broderipi Barrande, 1865 (C). Ventral view. Scale bar equal $10 \mathrm{~mm}$.

ted. In the first, fossil cephalopod assemblages have been considered to be essentially natural and thus only slightly affected by post-mortem drift of the shells (Flower 1957 and previous references therein). The second approach suggests that there is a large proportion of long-term drifted shells in the fossil assemblages (Miller \& Furnish 1937, Miller \& Youngquist 1949, Tasch 1955, Reyment 1958 and others). The latter opinion seems to be supported by observation of long-term drift by surface currents in recent Nautilus shells, as described and interpreted by Reyment (1958), Stenzel (1964), and Teichert (1970).

However, Collins \& Minton (1967) showed that water permeability of the connecting rings in Nautilus makes long-term drift of the shells problematic (see Turek 1974). Subsequently, Chamberlain et al. (1981) studied post-mortem behaviour of Nautilus shells and pointed out that extensive post-mortem drift of the shell is a relatively rare event. Palaeozoic cephalopods usually have uncoiled and commonly rapidly expanding shells. This type of shell geometry is less suitable for post-mortem drift than that in Nautilus (Turek 1974).

Flower's earlier suggestion (1957) that the fossil record of Palaeozoic cephalopods would not seem to be compatible with the concept of extensive post-mortem transport was later confirmed by detailed analysis of the Late Ordovician cephalopod assemblages of the Cincinnati area (Frey 1989) and of the Silurian cephalopod assemblages of Wales (Hewitt \& Watkins 1980). A similar conclusion provided the present study of the cephalopod assemblages in the Prague Basin. The distribution pattern of cephalopod assemblages generally respects benthic communities in the Prague Basin. Detailed analysis showed that some cephalopod taxa are restricted to a specific benthic community even if more than one community is present within one facies. In addition, deep-related cephalopod assemblages across the slope were observed whereas different cephalopod assemblages occur in shallow water environments above wave base and in the middle slope and lower slope settings.

In summary, the Palaeozoic cephalopod assemblages keep the original structure of former communities, which were affected only slightly by local transport and subse- quent taphonomic processes. Although the long-term post-mortem transport of cephalopod shells cannot be excluded, it represents a mere confusion in the fossil record. Sedimentary processes such as storm events might cause transport of shells from shallower to deeper environments or even re-deposition of still older buried shells but shells from such deposits should be omitted from palaeoecologic studies aimed at understanding living communities.

\section{Distribution of phragmoceratids in the Prague Basin}

The replacement of black, anoxic graptolitic shales by laminated calcareous shales reflects the activation of surface currents during the latest Llandovery $O$. spiralis Zone (Fig. 1). These weak currents occasionally ventilated the bottom in shallower parts of the eastern Central and Pankrác segments of the Prague Basin (Kříž 1991) and thus a pioneer community accompanied by pelagic orthocerids and Phragmoceras munthei appeared there (for details see Manda 2007). The low-density population of Phragmoceras munthei consists mainly of ephebic shells with an open aperture whilst neanic stages and ephebic shells possessing contracted apertures are rare (Fig. 9). Phragmoceratids probably migrated to deeper water environments from a distant shallow-water environment and persisted with the coeval pioneer community for a short period (note that a coeval shallow-water facies is not present in the Prague Ba$\sin )$.

Large fragments (up to $8 \mathrm{~cm}$ wide) of Phragmoceras munthei cover the upper bedding plane of a single mudstone unit in an early Wenlock $C$. murchisoni Zone shale sequence in the eastern part of the Central Segment (Manda 2007). The mudstone unit reflects a depositional event in a deeper water setting dominated by shale sedimentation. Mud deposition was followed by the short-lived influence of currents that ventilated the anoxic sea floor as indicated by the appearance of a pioneer benthic community. Phragmoceratid shells, which are normally preserved as fragments suggest a relatively high-energy environment. There are two possible explanations of the phragmocerid 

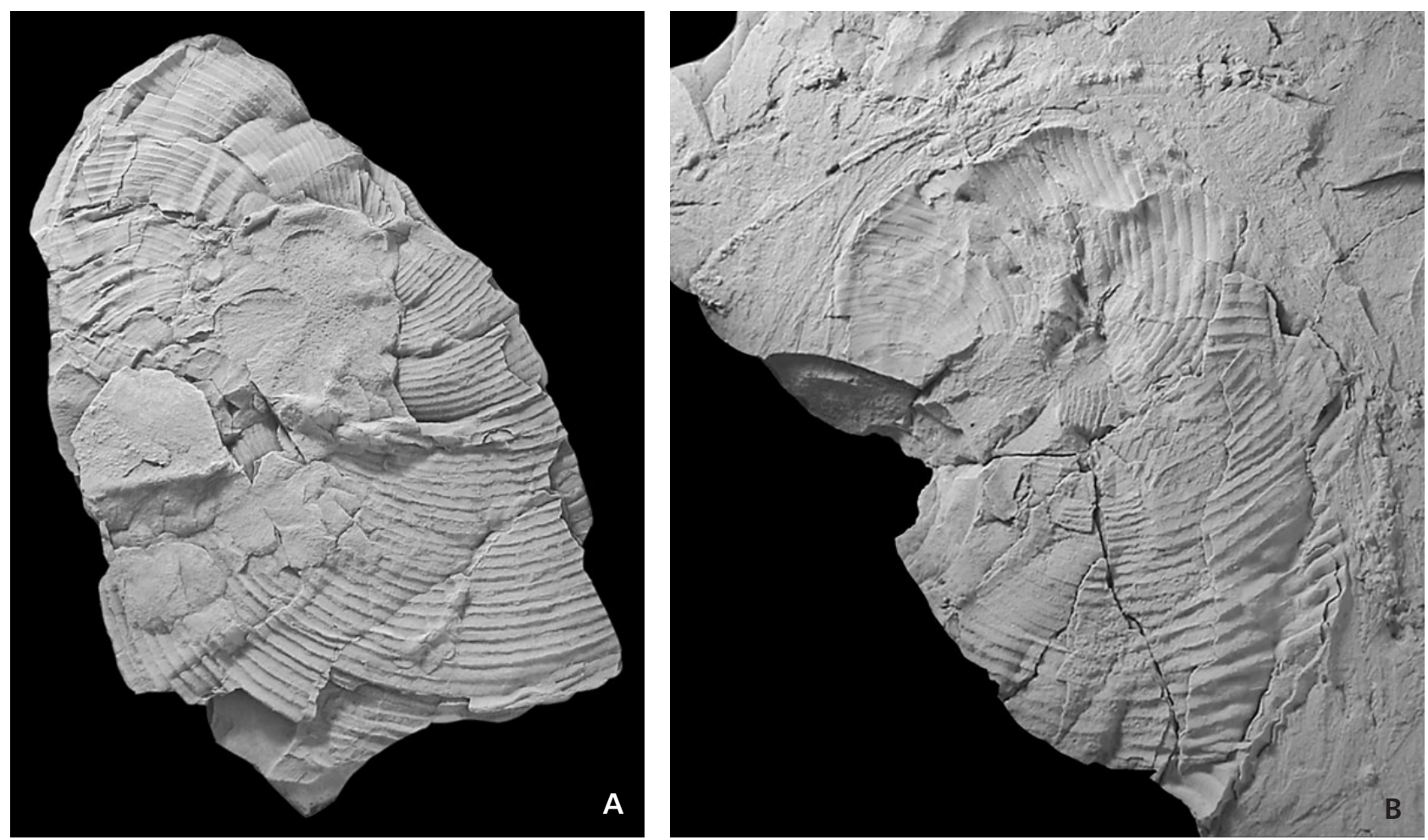

Figure 9. Phragmoceras munthei Hedström, 1917, Llandovery, Telychian, O. spiralis Zone. • A - Novoveská Gorge Section; CGS SM 82a; lateral view, $\times 1.1 . \cdot B-$ Braník U pivovaru Section; CGS SM 86; lateral view, $\times 1.3$.

accumulation: 1) the phragmoceratid shells were transported post-mortem to the deeper environment by currents; however, there is no other transported shallow-water shell material present; and, 2) the shell deposit reflects a selective mass immigration of phragmoceratids into a deeper biofacies due to an event that affected the shallow water environment hosting the phragmoceratid population.

In the late $C$. murchisoni Zone, submarine elevations of the Svatý Jan and Řeporyje volcanic centres (Kř́̌ž 1991) had originated and these extended further during the Sheinwoodian (Fig. 1). The floors of these elevations were colonised by incoming benthic communities (Havlíček \& Štorch 1990) with a rich brachiopod and trilobite fauna accompanied by the nectobenthic orthocerid Dawsonoceras annulatum (Sowerby, 1816). The phragmoceratid Tubiferoceras proboscoideum, together with four other nautiloid taxa, appear in limestones containing the Leptaena rugalita Community (Havlíček \& Štorch 1990), reflecting local shallowing in the M. belophorus Zone on the upper slope of the Svatý Jan Volcano (U elektrárny Section, Fig. 2: App. loc. 22). The coeval Sheinwoodian nautiloid faunas of Baltica and Avalonia are much more diversified than those in the Prague Basin. Low current activity accompanying the Sheinwoodian high-stand probably confined more cephalopod immigrations (Fig. 12) to the submarine elevations of the Prague Basin. An additional reason might have been the small area of shallow sea-floor in the region.
A rich cephalopod fauna, including many nautiloids (oncocerids, discosorids, barrandeocerids) and longiconic forms (orthocerids, pseudorthocerids, actinocerids) appeared in the early Homerian T. testis Zone. This sudden onset of a diverse cephalopod fauna indicates the first large-scale cephalopod immigration to the Prague Basin. Cephalopods are common in thin limestone beds just above thick basalt effusions. The cephalopod immigration coincides with shallowing and a low-stand reflected in the extension of the shallow-water carbonates surrounding the volcanic elevations (Kř́ž 1991). Carbonate sedimentation and faunal radiation reflected a break in volcanic activity after the large earlier Homerian basalt effusions, i.e., volcanic activity gave rise to the submarine elevations and the subsequent break in volcanic activity permitted colonisation of these basin highs. Further evolution of nautiloid immigrants, e.g., Phragmoceras (Fig. 12) on the volcanic elevations was limited by recurrent volcanic activity and the deposition of pyroclasts (pyroclastic confined biofacies of Havlíček 1995) and by global changes related to the Lundgreni Event (Melechin et al. 1998).

Five taxa of phragmoceratids occur in the T. testis Zone. Whilst Phragmoceras sigmoideum and Phragmoceras cf. undulatum are closely related (Manda 2007), the other species differ in shell shape and represent separate branches of Phragmoceras. As a rule phragmoceratids are rather rare, but they occur in different environmental set- 
tings and communities, and each ontogenetic stage is present (Figs 12, 13). The relatively thick-shelled Phragmoceras cf. ventricosum occurs in shallow water sediments considered to have been deposited above wave base and close to the feeder channel of the Svatý Jan Volcano (Lištice U cestičky Section No. 759, Fig. 2: App. loc. 13). A similar environment was occupied by Phragmoceras cf. undulatum (Lištice, exact site unknown) and by Phragmoceras biimpresum (Bubovitz e1: App. loc. 3). Phragmoceras acuminatum with a thinner and smaller shell occurred commonly in the slightly deeper high-energy environment of the upper slope of the Svatý Jan Volcanic elevation (Lištice Herinky, Fig. 2: App. loc. 12). A single specimen of Phragmoceras acuminatum was found in the cephalopod limestone reflecting brief surface current activity above the basaltic deposits of the Reporyje Volcanic Centre (Arethusinová Gorge Section No. 687, Fig. 2: App. loc. 1).

During the latest Wenlock (i.e. between the Lundgreni Event and the base of the Ludlow), nautiloids are missing. A diverse cephalopod fauna including nautiloids (oncocerids, discosorids, barrandeocerids, tarphycerids and ascocerids) suddenly reappeared in the early $N$. nilsonni Zone with the reappearance of the cephalopod limestone biofacies. This second large-scale cephalopod immigration and radiation coincides with a low-stand and break in volcanic activity. While in the Wenlock phragmoceratids occurred mostly in the shallow-water brachiopod limestone, the earlier Ludlow Phragmoceras imbricatum is preserved in a cephalopod limestone deposited on the upper slope of Nová Ves Volcanic centre elevation (Butovice Na břekvici Section No. 584, fig. 2; Barrande 1865, Kříž 1992: App. loc. 4). All ontogenetic stages are present there; specimens with open aperture prevail slightly over shells with a contracted aperture.

The earlier Ludlow low-stand was terminated by the middle Gorstian high-stand, which caused the retrogression of the cephalopod limestone biofacies (Manda \& Kř́iž 2007). In shallow-water facies, the fauna was restricted by an increased pyroclastic input. These changes caused the extinction of many nautiloids. Phragmoceras imbricatum is one of the few nautiloids surviving from the early $N$. nilsonni Zone into the early L. scanicus Zone. It occurs rarely in a local bed of cephalopod limestone at Vyskočilka e1 locality (Barrande 1865: App. loc. 25) and of coral-gastropod limestone (Řeporyje Section 911, Liščí Quarry, and Kosov, "new quarry”, SW wall: App. locs 21, 8).

A third cephalopod immigration-radiation coincided with the low-stand and extension of the shallow areas over elevations in the $S$. linearis Zone (Fig. 1). The extension of carbonate sedimentation and faunal radiation was also related to the lack of volcanic activity.

Four species of Phragmoceras appeared; these taxa are morphologically distinct from each other and represent separate branches within the genus. Phragmoceras labiosum, Phragmoceras longum and Phragmoceras koneprusensis are rare whilst Phragmoceras broderipi sublaeve is relatively common.

Phragmoceras labiosum with a small shell (Fig. 4) occurs in cephalopod wacke-packstones (Hinter Kopanina e2, Konieprus e2, Barrande 1865: App. locs 5, 7) and brachiopod-cephalopod grainstones (U lanovky Section: App. loc. 23). Phragmoceras longum (Fig. 4) with a larger and more cyrtoconic shell occurs in cephalopod wacke-packstones (Lochkov e2, Hinter Kopanina e2, Barrande 1865; Horní Desort Quarry near Zadní Kopanina: App. locs 5, 6, 14). A single shell belonging to Phragmoceras koneprusensis was found in a cephalopod grainstone in the Velký Hill Section near Koněprusy: App. loc. 24 (Fig. 2).

Phragmoceras broderipi sublaeve, with a relatively large and coiled shell occurs commonly at several localities; most commonly in cephalopod wacke-packstones, but also in deeper water mudstones as well as shallow-water fine-grained trilobite-brachiopod grainstones. Phragmoceras broderipi sublaeve is the only phragmoceratid taxon to appear in the late $S$. linearis Zone, and which survived the deepening in the B. bohemicus tenuis Zone persisting into the N. inexpectatus Zone (e.g., Kosov Quarry - "old quarry", Lochkov-Barrande's pits, Velký Hill Section, and Zadní Kopanina Jiras Quarry, Mušlovka Quarry: App. locs $9,15,17,24,27)$.

The closely related Phragmoceras broderipi broderipi first appeared in the $N$. inexpectatus Zone. It was most common in this zone when shallow-water brachiopod limestones extended over the elevated parts of the basin during the low-stand (Fig. 11). Later, the species occurred mainly in brachiopod pack-grainstones, and less commonly in cephalopod limestones (Fig. 10). A decrease in numbers took place in the duration of the overlying $N$. kozlowskii Zone when the brachiopod limestone facies was replaced by cephalopod limestones during and in the subsequent high-stand (e.g., Kovářovic mez - Butovice, Nová Ves Hradiště II Section and Lochkov - Barrande's pits: App. locs 10, 15, 18).

The last phragmocerid recorded from the Prague Basin is Phragmoceras beaumonti (Figs 12, 13), which appeared in the cephalopod wackestones of the N. kozlowskii Zone (Kř́ǐ̌ 1998, Manda \& Kř́ž 2006), e.g., in Mušlovka and Požáry quarries at Řeporyje, Nová Ves-Hradiště and Lochkov-Barrande's pits: App. locs 15, 17, 18, 20 (Figs 2, 11). Phragmoceras beaumonti is evidently derived from the Phragmoceras broderipi broderipi, and both later taxa occur together in the early N. kozlowskii Zone.

Phragmoceras broderipi broderipi became less abundant during the deepening in the N. kozlowskii Zone. Some individuals reached maturity, but the overall size of the shell was smaller, whilst the shells of immature individuals 


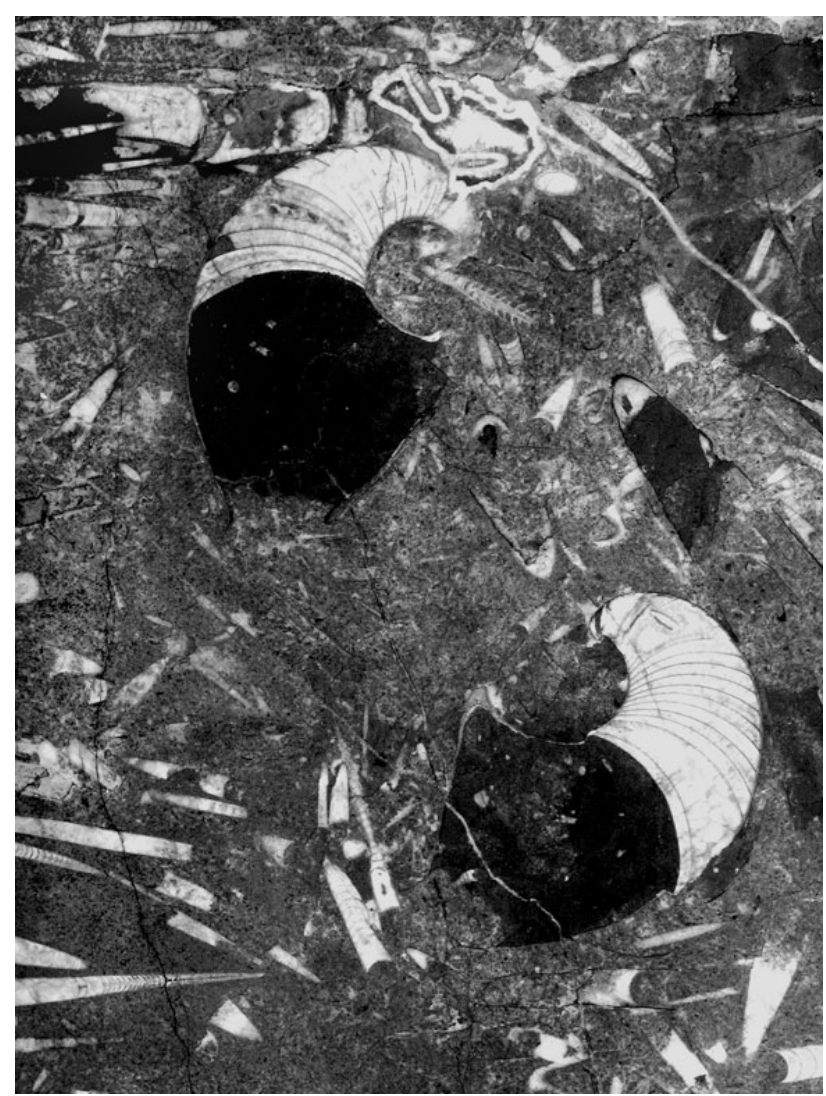

Figure 10. Polished slab of Silurian cephalopod limestone showing two specimens of Phragmoceras broderipi broderipi Barrande, 1865. Most probably from the middle Ludfordian, of Zadní Kopanina, Jiras Quarry, $\times 0.4$. Facing stone in the entrance of the Ministry of Finance of the Czech Republic, Letenská Street, Malá Strana, Praha.

make up a larger proportion of the population, suggesting a high mortality rate. Shells similar to immature specimens of Phragmoceras broderipi broderipi (i.e., with open aperture), with more strongly coiled shells but lacking the distinctive annulations, appeared simultaneously with the decline of Phragmoceras broderipi broderipi. These smaller shells are here regarded as Phragmoceras beaumonti. Within the late N. kozlowskii Zone, only those specimens with an open aperture and more strongly coiled shells have been found. Thus Phragmoceras beaumonti should be considered as a distinctive species. The loss of the contracted aperture and the small size of later species probably reflect adaptation to deeper water and a less ventilated environment during the high-stand of the N. kozlowskii Zone (Figs 12, 13).

\section{Extinction of phragmoceratids}

In the Prague Basin the last phragmocerid record, that of Phragmoceras beaumonti is from the uppermost N. kozlowskii Zone, i.e., just below the Kozlowskii Event
(Figs 12, 13). In Gotland, the last phragmoceratid record is from the Hemse Beds, the uppermost part of which can be correlated with the $N$. kozlowskii Zone (Jeppsson \& Aldridge 2000, Manda \& Kříž 2006). Holland \& Stridsberg (2004, p. 302) did not assume the extinction of Phragmoceras at this level, but attributed the lack of Phragmoceras in the beds overlying the Hemse Beds to the fact that the majority of these units comprise a regressive succession unsuitable for nautiloids. Outside the Prague Basin and Gotland phragmoceratids disappeared even earlier: during the Gorstian and earlier Ludfordian, respectively. The Kozlowskii Event reflects changes in global oceanic circulation, causing rapid deepening and shallowing cycles, climatic changes including cooling (e.g., Melechin et al. 1998, Manda \& Kř́ž 2006, Lehnert et al. 2007), and most probably was the cause of the worldwide extinction of Phragmoceras.

\section{Migration of the Phragmoceras}

\section{Mode of dispersion of the phragmoceratids}

The Silurian phragmoceratids show features characteristic of a K-selected cephalopods: slow growth rate, long life, large protoconch, large shell, absence of a pelagic stage and low juvenile mortality. The majority of phragmoceratids inhabited stable, warm, well-ventilated, shallow-water environments extending across the Silurian carbonate platforms of Laurentia and Baltica, which had been evolutionary centres for nautiloids.

Fossil nautiloids are usually compared with the Recent Nautilus, for which dispersion limiting factors are well known, water temperature and the local condition of the sea-floor being the most important (Ward 1987). A nectobenthic mode of life and similar morphology of the shell at all ontogenetic stages is another limiting factor (Chirat \& Rioult 1998). Earlier nautiloids generally exhibit similar restrictions to Nautilus. Here it should be noted that Silurian nautiloids commonly exhibited relatively large geographic dispersions by comparison with Ordovician and post-Silurian nautiloids. Amongst Silurian nautiloids, Phragmoceras exhibits one of the most dispersed taxa; occurring in all low-latitude palaeocontinents with the exception of China. By comparison, the morphologically convergent Devonian oncocerids (e.g., Metaphragmoceras Flower, 1938) exhibit a restricted distribution and narrow range.

There are two modes of nautiloid dispersion: along shelves and by warm surface currents (see Chirat \& Rioult 1998). Transport by currents was common among cosmopolitan 'orthocerids' with small pelagic post-hatching stages, but was rare among nautiloids, which thus exhibited a restricted dispersion. By comparison with the currents 

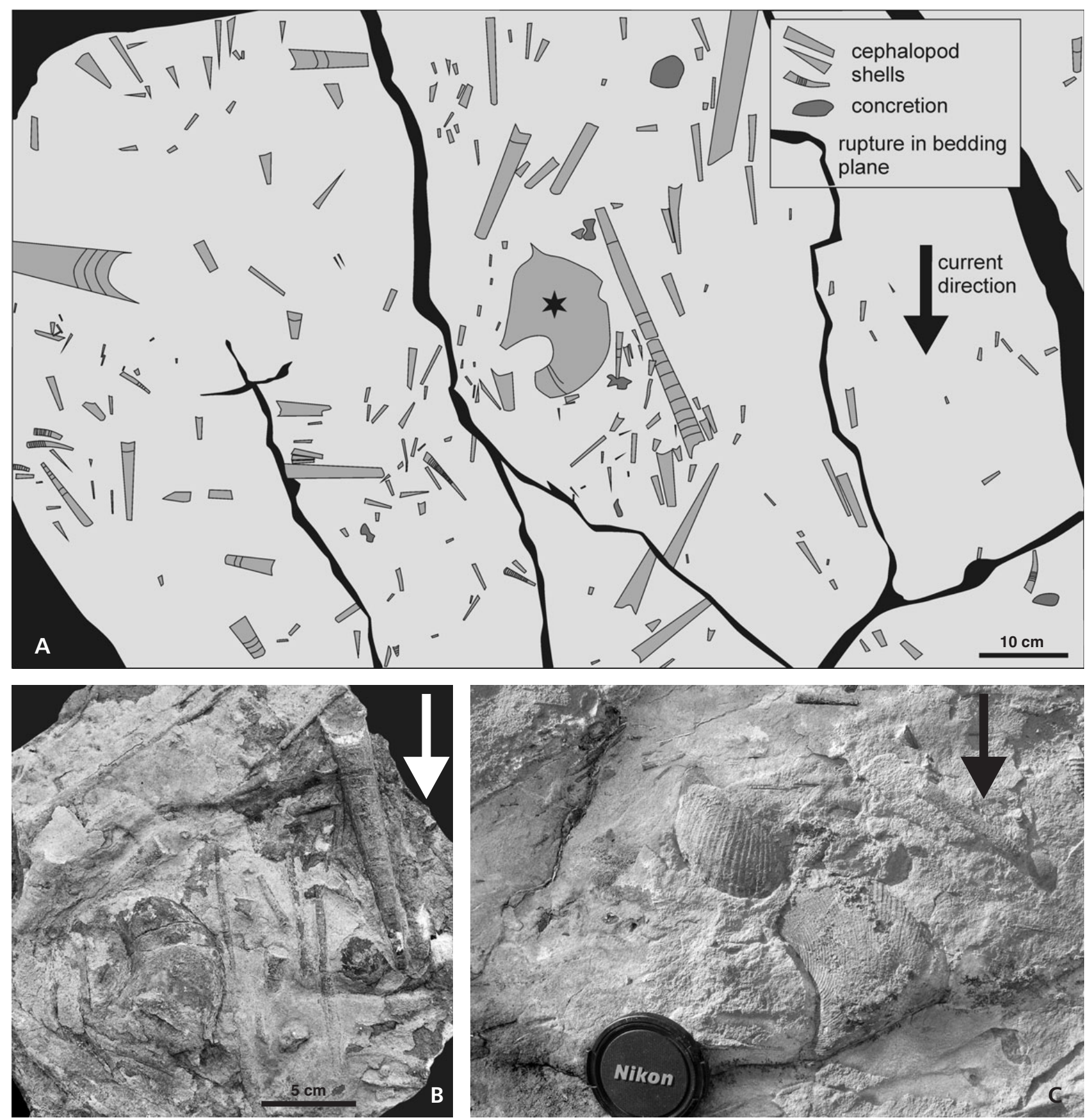

Figure 11. Mode of preservation of Phragmoceras broderipi broderipi in the cephalopod limestone, upper bedding plane of the bed No. 10, Kosov Section No. 782 (see Křřž 1992), Ludlow, Ludfordian, upper N. inexpectatus Zone. About $33 \mathrm{~m}^{2}$ of the bedding plane was recovered during spring 2007. Eight specimens of Phragmoceras broderipi broderipi were observed: four shells with contracted aperture (A, C), two shells with open aperture (B) and two large fragments (C). Each phragmoceratid shell was oriented toward current by anterior or posterior side (see also Fig. 9). After unpublished data collected by J. Kříž and Š. Manda. • A - A line drawing showing arrangement of the cephalopod shells, Phragmoceras broderipi broderipi indicated by asterisk. $\bullet \mathrm{B}$ - a shell of Phragmoceras broderipi broderipi with open aperture, field photograph. $\bullet \mathrm{C}-$ two specimens of Phragmoceras broderipi broderipi, fragment of the lateral part of the shell and body chamber with part of the phragmocone, field photograph. Current direction indicated by arrow.

that passively transported and dispersed 'orthocerids', adult nautiloids dispersed through active swimming. The evidence of colonisation of submarine elevations by adult immigrants can be seen in their rare finds together with common juvenile 'orthocerids' in basin shales.
Closely related Silurian nautiloid faunas occur in Baltica, Avalonia and Laurentia where the shelves provided favourable conditions for nautiloid dispersion (Fig. 14). There are many common genera and even species originally described under different names from England, 


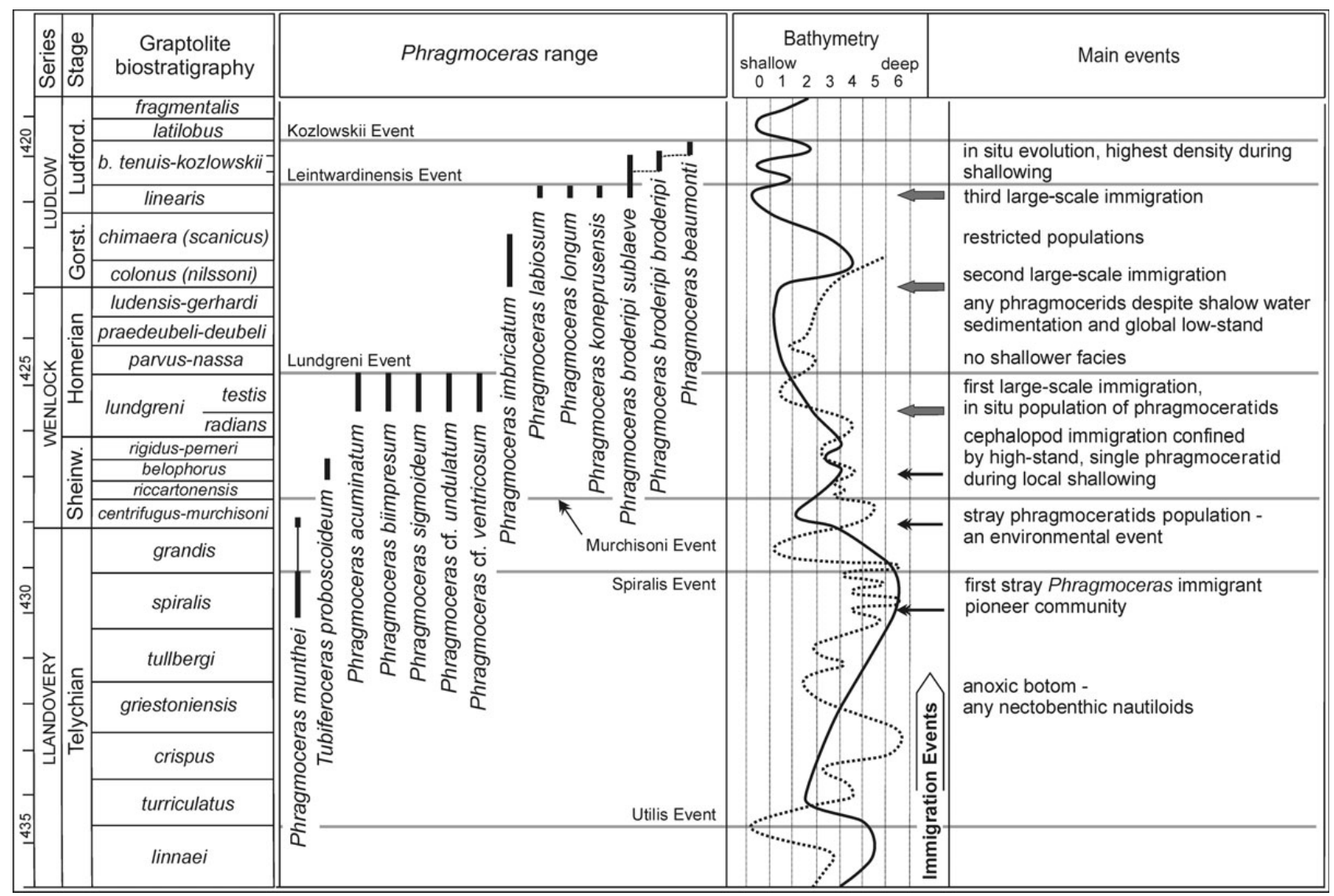

Figure 12. The stratigraphic range of phragmoceratids, immigration events, eustatic oscillations and main events of the phragmocerid succession in the Prague Basin. First eustatic curve (solid line) after Johnson et al. (1998) for the Llandovery-early Ludlow and Manda \& Křǐz (2006) for the Ludfordian; second curve after Loydell (1998).

North America, Gotland and Bohemia (Stridsberg 1985, Stridsberg \& Turek 1997, Holland \& Stridsberg 2004).

Nautiloids of the same genera (rarely species) also occur in the carbonate platforms of Kazakhstania and Siberia (Kiselev et al. 1993, Kiselev 1998), which were located within warm water masses to the north of the contemporary equator (Wilde et al. 1991) and separated from Laurentia, Baltica and Avalonia by great oceanic depths (Fig. 14). In this case, nautiloid immigrations via a north tropical current (Wilde et al. 1991) are presumed.

\section{Stages of immigration to the Prague Basin}

Closely related nautiloid faunas occurred in the Prague Basin, located in the temperate zone and separated from Baltica-Avalonia by the Rheic Ocean (Figs 14, 15). During the Silurian, the Prague Basin was situated on the microplate Perunica (Fig. 13), close to the northern margin of peri-Gondwana shifting toward to the equator (Havlíček et al. 1994, Krs et al. 2001, Cocks \& Torsvik 2002). Widespread anoxia in the peri-Gondwanan basins during the ear- liest Silurian limited the distribution of nectobenthic cephalopods, which needed a well-oxygenated water column. Thus nautiloid immigration was not initiated until the late Llandovery. Three stages of nautiloid immigration into the Prague Basin are recognised: stray immigrants; in situ populations of immigrants; and their progenitors (Figs 12, 13).

1) Stray immigrants. - The early immigration of Phragmoceras into the Prague Basin can be compared with the immigration of Recent adult living Nautilus by currents from the main populations, e.g., from the Philippines to Kyushu Island, Japan (Hamada et al. 1980). Reproduction of Nautilus in Japan is limited by low temperature. The latest Llandovery-early Wenlock phragmoceratids represent such ancient stray immigrants of Baltic-Avalonian origin. The early Wenlock accumulation of Phragmoceras munthei in a single bed suggests a "stray population" reflecting an environmental event. There is no correlation between eustatic oscillation and immigrations (see Fig. 12).

2) In situ populations. - The majority of late Wenlock phragmoceratids occurred in shallow-water brachiopod li- 


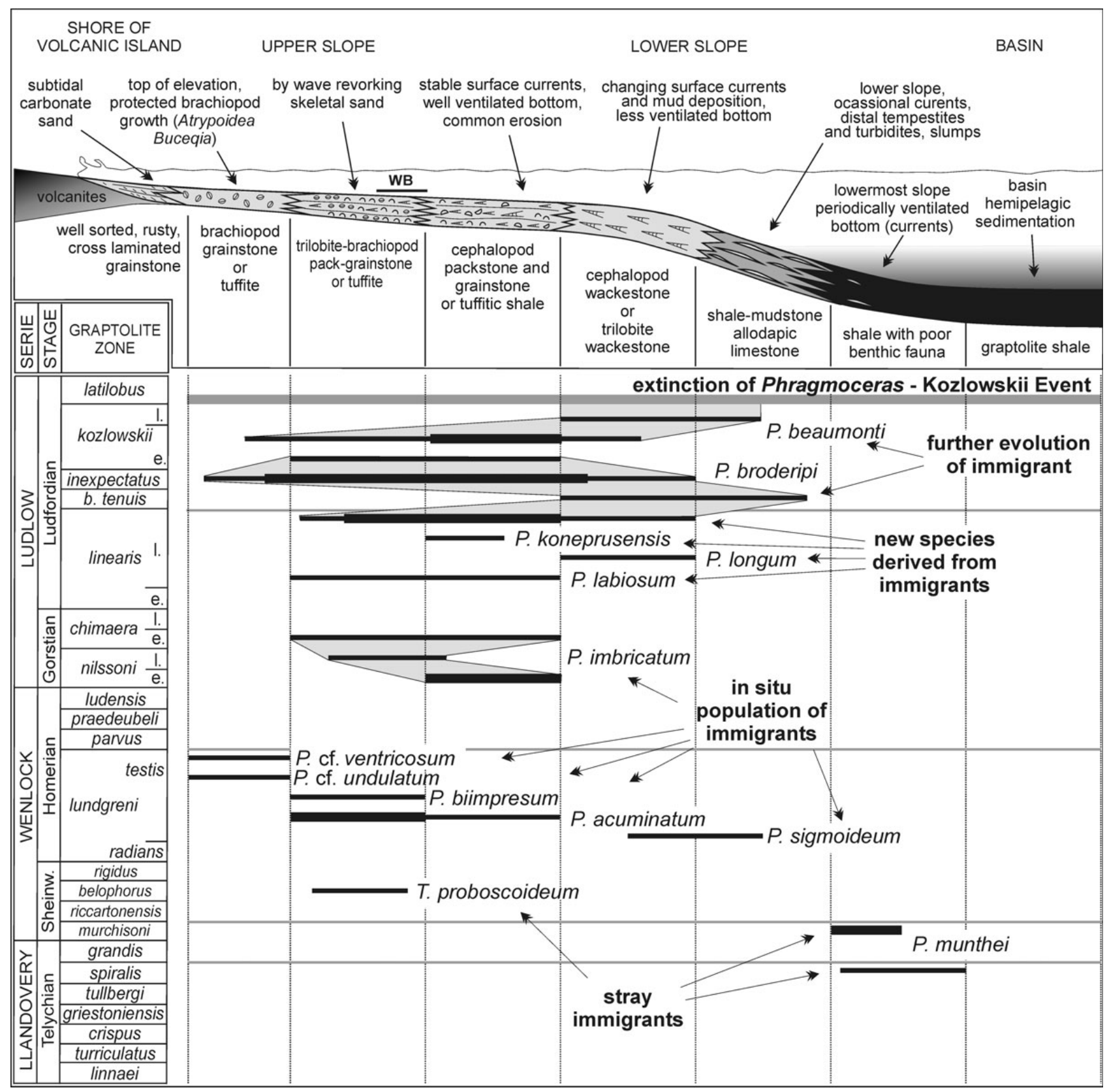

Figure 13. Distribution of Silurian phragmoceratids of the Prague Basin in relation to the facies (depth) zones. Not to a time scale. Grey areas indicate continual evolution of a species. The distribution of phragmoceratids is compared with the global eustatic curve (Fig. 12) and the lithostratigraphy of the Prague Basin (Fig. 1). Abbreviation: WB - wave base.

mestones, whereas in the early Ludlow the majority of them are to be found in the cephalopod limestone biofacies (Fig. 13), representing deeper-water environments. In situ populations of immigrants appeared during low-stands (T. testis, N. nilsoni zones), but did not survive the subsequent deepening (Fig. 13). The presence of each ontogenetic stage including early post-hatching specimens during the late Wenlock and later permits their interpretation as in situ populations of phragmoceratid immigrants on submarine volcanic elevations in the Prague Basin. All pragmo- cerid immigrants are of Baltic or Avalonian origin and form small populations on these submarine elevations.

The presence of post-hatching specimens is worthy of comment. Recent Nautilus embryos live in water at temperatures of $22-24{ }^{\circ} \mathrm{C}$ with a long incubation period, 9.5-14 months in aquaria (Ward 1987). Jurassic nautilids hatched in slightly cooler water with a lower limit of $19.5^{\circ} \mathrm{C}$ (Chirat \& Rioult 1998). The size of the shell and protoconch of Phragmoceras is similar to that of Nautilus. Thus the recognition of early post-hatching specimens and 


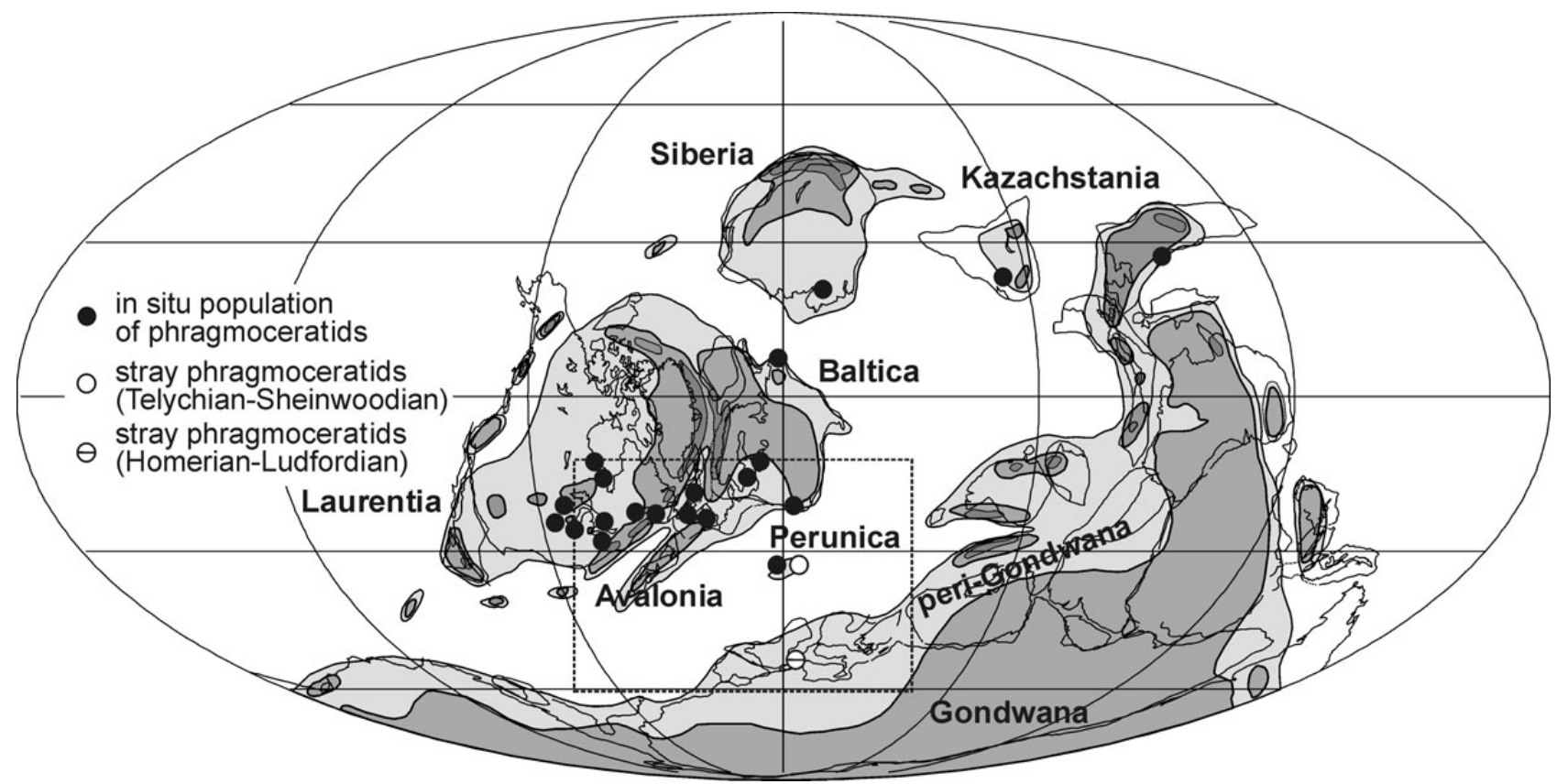

Figure 14. Distribution of phragmoceratids. Wenlock palaeogeographic reconstruction based on the Paleomap Project of C.R. Scotese; Perunica microplate position after Krs et al. (2001) and Cocks \& Torsvik (2002). Data set: Prague Basin (Manda 2007), Gotland (Hedström 1917, Holland \& Stridsberg 2004), Estonia (Kiselev et al. 1990), Podolia in Ukraine (Kiselev 1986, Kiselev et al. 1987), North Ural (Kiselev 1984), Siberia (Kiselev 1998), Severnaya Zemlya (Bogolepova et al. 2000), Inner Mongolia (Zou 1983), Tian Shan (Kiselev et al. 1993), Illinois, Indiana, New York, Ohio, Ontario, Quebec, Wisconsin (for summary see Flower \& Teichert 1957), Scotland (Holland 2000), Wales and the Welsh Borderland (Murchison 1839, Blake 1882, Holland \& Stridsberg 2004), Ireland (Evans 2002), and Sardinia (Stridsberg 1988; Gnoli 1990, 1993).

local populations suggests relatively temperate water in the Prague Basin during the late Wenlock.

Nevertheless, the temperature of water could not have been as high as in the subtropical and tropical waters enabling the incubation of Nautilus and post-Triassic nautilids. This is indicated by the absence of warm-water carbonates and associated biota. It can be presumed that phragmoceratids in the Prague Basin as well as accompanying nautiloids, including the ancestors of Nautilus, were able to reproduce in temperate waters.

3) Further evolution of immigrants. - The early Ludfordian phragmoceratids are represented by local taxa, whilst allied taxa have been described from Baltica. This suggests further evolution (peripatric speciation) of immigrants during the early Ludfordian low-stand (S. linearis Zone) and thus the presence of more stable conditions needed by nautiloids. Only one of four phragmoceratids described from the $S$. linearis Zone survived the deepening event in the B. tenuis Zone and continued to evolve up to the Kozlowskii Event (Figs 12, 13). The Ludfordian phragmoceratids occur mainly in the cephalopod limestone biofacies. The adaptation of immigrants to the deeper-water cephalopod limestone biofacies with intense surface currents and a less stable environment is of note during the Wenlock-Ludlow in the Prague Basin (Fig. 13).

\section{Nautiloid immigrations to the others peri-Gondwanan terrains}

Two phragmoceratids were described from the cephalopod limestones of Sardinia (Figs 14, 15); the late Wenlock Phragmoceras sp. (Phragmoceras broderipi sublaeve in Gnoli 1990) and the Ludfordian Phragmoceras labiosum (Gnoli 1993). Both species are based upon a single mature shell and probably represent stray immigrants from warmer seas, as suggested by Stridsberg (1988). Phragmoceras labiosum indicates faunal links with the Prague Basin as do the majority of the cephalopod assemblage(s) (Gnoli 1993).

In the Prague Basin, stray immigrants appeared in the late Llandovery and then after the late Wenlock, only endemic populations were present. In Sardinia, located further to the south, stray immigrants appeared very late in the Wenlock and there is no evidence of in situ phragmoceratid populations during the Silurian. A similar migration pattern is exhibited by other nautiloids of Sardinia and the Carnic Alps (e.g., Gnoli 1990, 2003). Nautiloid dispersion in peri-Gondwana (except Perunica) was probably limited by low water temperature. The distribution of nautiloid assemblages confirms the distinctive position of the Perunica microplate in northern peri-Gondwana, within reach of warm currents (Fig. 15). 


\section{Comparison of phragmocerid palaeo-population from Gotland and Prague Basin}

As noted above, the phragmoceratids of the Prague Basin are immigrants from warm water carbonates platforms or represent closely related species that evolved from these immigrant ancestors. In total 14 phragmocerid taxa are reported from the Prague Basin. This is the second most diversified local fauna of phragmoceratids after Gotland, where 24 taxa are known (Holland \& Stridsberg 2004). Amongst these, probably six species are in common to both places. Certain other species are closely related to taxa that occur in Gotland or Britain. Are there some differences in the structure of the palaeo-populations from Gotland and the Prague Basin (i.e., between warm and temperate water, respectively)? The majority of phragmoceratids from Gotland occurred in very shallow-water environments close to reefs; in the Prague Basin they generally inhabited deeper-water environments lacking reefs. In the Prague Basin, the majority of phragmoceratids occur in cephalopod limestones, in which common juvenile bivalves indicate occasional anoxic conditions in the lowermost part of the water column (see Ferretti \& Křižz 1995, Kř́̌ž 1998). Locally common pelagic cephalopods document current instabilities in the water column, which caused mass mortality of pelagic cephalopod para-larvae.

Compared with the number of phragmocerid specimens known from Gotland, the phragmoceratids of the Prague Basin are usually rarer. Exceptions to this are the Ludfordian Phragmoceras broderipi and Phragmoceras beaumonti, which represent an endemically evolved clade. In addition, the phragmoceratid populations of the Prague Basin commonly contain specimens with open apertures. During the latest Llandovery, Wenlock and early Ludlow the early stages with an open aperture form a significant portion of fossil samples. It can thus be concluded that phragmocerid palaeo-populations in the Prague Basin were subjected to relatively high mortality rates. By contrast, phragmoceratids from Gotland exhibited fairly low mortality rates; only a single specimen with an open aperture (i.e., died before maturity and aperture closure) is present amongst several specimens with contracted aperture, figured by Hedström (1917).

Another interesting difference is shape variation. Phragmoceratids from the Prague Basin exhibit fairly low shape variability when compared with those from Gotland. The difference is expressed by well-defined and discreet morphologies in the Prague Basin, whereas in Gotland only "a few specimens are really identical" (Holland \& Stridsberg 2004, p. 302). Thus the phragmoceratids that migrated to the Prague Basin carried only a small part of the phenotypic variability of Gotland's population and thus morphological variability was lower. The lower variability of phragmoceratids in the Prague Basin may indirectly sug-

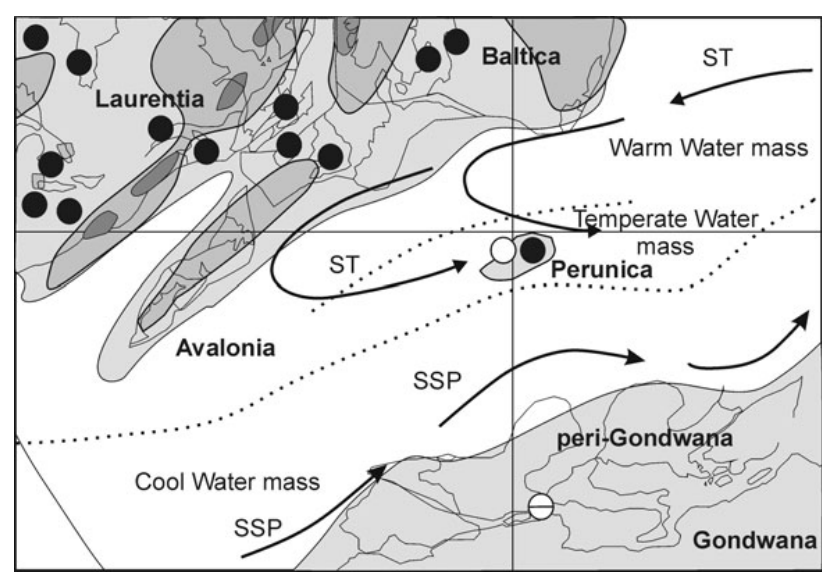

Figure 15. Phragmoceratid distribution around the early Silurian Rheic Ocean and adjacent areas (detail of map given as Fig. 8) showing reconstruction of oceanic currents (Wilde et al. 1991) and distribution of warm and cool water masses. Abbreviations: ST - South Tropical Current, SSP - South Subpolar Current.

gest that a relatively small number of migrants were involved.

In summary, the low density, high mortality, and small range of morphological variations of the phragmoceratids is considered to reflect less suitable environmental conditions for and higher adaptive pressure of nautiloids in the Prague Basin.

\section{Why immigrations coincided with low stands?}

The appearance of nautiloids during the late Llandovery suggests that the Perunica was reached via a South Tropical Current directed along the southern margin of Baltica-Avalonia and across the Rheic Ocean (Kř́iž 1979, Wilde et al. 1991, here Fig. 14). Latest Llandovery and Early Wenlock nautiloid immigrations to the Prague Basin (Fig. 9) show features reflecting an ecosystem recovery after the early Silurian anoxia event (post-extinction stage boundary of Jablonski 2001). It is notable that these early immigrations were initiated after short-lived glaciations followed by global warming (Caputo 1998).

The subsequent migrations (Figs 12, 13) of nautiloids coincided with low-stand episodes. Chirat \& Rioult (1998) assumed that low stands allowed nautiloids to swim along the sea floor, which were previously below their implosion depths. The great depth of the Rheic Ocean (i.e., between Baltica and Perunica) must have persisted despite eustatic oscillations. The correlation between migrations and low stands requires another explanation. For example the retreat of carbonate sedimentation, and the emergence of carbonate platforms during low stands accompanied by a decrease in the area of shallow seas (e.g., Jeppsson 1990) along Baltica could have pressed nautiloids to search for new 
living places. Such new eco-space might have been offered by sites on northern peri-Gondwana located in temperate zone, where during low-stands submarine elevations ventilated by currents were extended in area. Increasing migration and the subsequent endemic evolution of phragmoceratids is reflected in a stepwise decrease in distance between Baltica-Avalonia and Perunica (i.e., closure of the Rheic Ocean) as well as warming caused by the shift of Perunica (peri-Gondwana) toward to the equator and accentuated by global warming during the Silurian (Frakes et al. 1992).

\section{Comparison of distribution pattern of phragmoceratids and other nautiloids: is the size of embryonic stage a limiting factor to dispersion?}

Many other Silurian nautiloids exhibit similar distribution and migration patterns to the phragmoceratids; e.g., Euryrizoceras Foerste, 1930 (Sheinwoodian-Přídolí), Octameroceras Hyatt, 1884 (Homerian-Přídolí), Oonoceras Hyatt, 1900 (Sheinwoodian-Lochkovian) and Peismoceras Hyatt, 1884 (Sheinwoodian-Přídolí, Turek 1976); and whereas Phragmoceras disappeared during the Late Ludfordian Kozlowskii Event, other nautiloids continued to evolve during the latest Silurian. The morphological contrasts between the phragmoceratids and the nautiloids that survived after the phragmoceratid extinction generally are based on few differences. The nautiloid clades that survived the Kozlowskii Event have smaller embryonic shells. Furthermore, nautiloids with a smaller embryonic stage exhibited a higher rate of speciation and commonly composed a larger and more stable palaeo-population than phragmoceratids in the Prague Basin. It is possible that the difference in ontogenetic pattern, i.e., size of embryonic shell, of the nautiloid families was linked to different reactions to rapid environmental abrupt change such was the late Ludfordian Kozlowskii Event.

In general, the large eggs of present cephalopods have a rather longer incubation time than smaller eggs (e.g., Boletzky 1994). If this were also true of Palaeozoic nautiloids, the eggs of those with large apices and hatching size (e.g., Phragmoceras) offered a longer time for predators and changing environment. An inverse correlation between temperature and duration of embryonic development (e.g., Boletzky 1994) is another important factor relevant to cephalopod dispersion in the past. This suggests that embryos developed in temperate water (e.g., Prague Basin) longer than on tropical platforms. Embryonic life extension left eggs open to changing environment and predators for more times. In addition, the seasonal fluctuations accompanying especially icehouse climate would have affected populations of nautiloids; effect of these on coleoid cephalopods was summarised by Leporati et al. (2007).
In summary, nautiloids with a large embryonic chamber and hatching size were under higher evolutionary pressure especially during any period of rapid environmental change. An example might be the extinction of Phragmoceras at the Kozlowskii Event during which the green house climate passed into icehouse climate (Lehnert et al. 2007).

\section{Acknowledgments}

David H. Evans (Natural England, Peterborough) and Björn Kröger (Museum für Naturkunde, Berlin) are deeply acknowledged for manuscript revision and valuable suggestions substantially improving this paper. Many thanks to Jiři Kříž from the Czech Geological Survey, Prague for a critical reading of an early draft of the manuscript. Susan Turner (Queensland Museum, Brisbane) and Zuzana Tasáryová (Czech Geological Survey, Prague) kindly made language corrections. Vojtěch Turek (National Museum, Praha) kindly made accessible the collection of J. Barrande. The research was funded by GA ČR (Czech Science Foundation) project 205/06/1367. This study is contribution to UNESCO-IUGS IGCP Project 503 Ordovician Palaeogeography and Palaeoclimate.

\section{References}

ABEL, O. 1916. Paläobiologie der Cephalopoden aus der Gruppe der Dibranchiaten. 281 pp. Fischer, Jena.

AgASSIZ, L. 1847. An introduction to the study of Natural history, in a series of lectures delivered in the hall of the College of Physicians and Surgeons. 58 pp. Greeley \& McElrath, New York.

BARRANDE, J. 1865-1877. Systême silurien du Centre de la Bohême, I ${ }^{\text {ère }}$ partie: Recherches Paléontologiques, vol. II, Classe de Mollusques, Ordre des Céphalopodes, 1865. ser. 6, pl. 1-107; 1866. ser. 7, pl. 108-244; 1867. ser. 1, 712 pp.; 1868. ser. 8, pl. 245-350; 1870. ser. 2, 266 pp., ser. 9, pl. 351-460; 1874. ser. 3, 804 pp.; 1877. ser. 4, 742 pp., ser. 5, 743 pp., supplement 1, 297 pp., supplement 2, pl. 461-544. Published privately, Prague \& Paris.

BASIL, J.A., HANLON, R.T., SheikH, S.I. \& ATEMA, J. 2000. Three-dimensional odor tracking by Nautilus pompilius. Journal of Experimental Biology 203, 1409-1414.

BASSE, É. 1952. Classe de Céphalopodes, 461-755. In PIVETEAU, J. (ed.) Traité de Paléontologie. Masson et Cie, Paris.

BlAKE, J.F.A. 1882. A monograph of the British fossil Cephalopoda, Part 1, Introduction and Silurian species. 248 pp. Palaeontographical Society, London.

Bogolepova, O.K., GubANOV, A.P. \& Loydell, D.K. 2000. New data on the Silurian of Severnaya Zemlya, Russian Arctic. Geologiska Föreningen Förhandlingar 122(4), 385-388.

BOLETZKY, S. 1994. Embryonic development of cephalopods at low temperatures. Antarctic Science 6(2), 139-142. DOI 10.1017/S095410294000210

BoUČEK, B. 1937. Stratigrafie siluru v Dalejském údolí u Prahy a 
v jeho nejbližším okolí. Rozpravy České akademie věd a umění, Třída II 46(27), 1-20.

BoUČEK, B. 1938. O výskytu dendroidů a jiné benthonní fauny v nejspodnějším českém wenlocku. Časopis Národního muzea, Oddíl př́rodovědecký 62, 171-172.

CAPUTO, M.V. 1998. Ordovician-Silurian glaciations and global sea-level changes. New York State Museum Bulletin 491, $15-25$.

BRODERIP, W. in MURCHISON, R.I. 1839. The silurian system, founded on geological researches in the counties of Salop, Hereford, Radnor, with descriptions of the coal fields and overlying formations. Part 1.768 pp. John Murray, London.

CARls, P., Slavík, L. \& VAlenzuela-Ríos, J.I. 2007. Revision of conodont biostratigraphy across the Silurian-Devonian boundary. Bulletin of Geosciences 82(2), 145-164. DOI 10.3140/bull.geosci.2007.02145

Chamberlain, J.A, Ward, P.D. \& Weaver, J.S. 1981. Postmortem ascent in Nautilus shells: implications for cephalopod paleobiogeography. Paleobiology 7, 494-509.

CHIRAT, R. \& RIOULT, M. 1998. Occurrence of early post-hatching Jurassic Nautilida in Normandy, France: palaeobiologic palaeoecologic and palaeobiogeographic implications. Lethaia 31, 137-148.

CHLUPÁČ, I. ed. 1987. Vysvětlivky k základní geologické mapě ČSSR 1 : 25 000, list Králův Dvưr 12-413. 108 pp. Ústřední ústav geologický, Praha.

COCKS, L.R.M. \& TORSVIK, T.H. 2002. Earth geography from 500 to 400 million years ago: a faunal and palaeomagnetic review. Journal of the Geological Society of London 159(6), 631-644.

Collins, D.H. \& MiNTON, F. 1967. Siphuncular tube of Nautilus. Nature 216(5118), 916-917. DOI 10.1038/216916b0

DEECKE, W. 1913. Paläeontologische Beotrachtungen. I. Über Cephalopoden. Neue Jahrbuch für Geologie und Paläontologie, Beilage-Band 35, 241-276.

DZIK, J. 1984. Phylogeny of the Nautiloidea. Paleontologia Polonica 45, 1-255.

EvANS, D.H. 2002. Some additional Ordovician and Silurian cephalopods from Ireland. Special Papers in Palaeontology 67, 77-96.

FERRETTI, A. \& KŘíž, J. 1995. Cephalopod limestone biofacies in the Silurian of the Prague Basin, Bohemia. Palaios 10(3), 240-253. DOI 10.2307/3515255

FLOWER, R.H. 1938. Devonian brevicones of New York and adjacent areas. Palaeontographica Americana 2(9), 1-84.

FLOWER, R.H. 1940. The superfamily Discosoridea (Nautiloidea). Bulletin of the Geological Society of America 51, 1969-1970.

FlOwER, R.H. in FLOwER, R.H. \& KUMMEL, B. 1950. A classification of the Nautiloidea. Journal of Paleontology 24(5), 604-616.

FLOWER, R.H. 1957. Nautiloids of the Paleozoic. Memoirs of the Geological Society of America 67(2), 829-852.

FlOWER, R.H. \& TEICHERT, C. 1957. The cephalopod order Discosorida. University of Kansas Paleontological Contributions, Mollusca 6, 1-144.
FOERSTE, A.F. 1926. Actinosiphonate, Trochoceroid and Other Cephalopods. Bulletin of Denison University, Journal of the Scientific Laboratories 21, 285-384.

FOERSTE, A.F. 1930. Port Byron and other Silurian cephalopods. Bulletin of Denison University, Journal of the Scientific Laboratories 23, 1-110.

FOERSTE, A.F. 1936. Silurian cephalopods of the Port Daniel area on Gaspé Peninsula, in eastern Canada. Bulletin of Denison University, Journal of the Scientific Laboratories 31, 21-92.

FRAKES, L.A., FrANCIS, J.E. \& SYKLUS, J.L. 1992. Climate modes of the Phanerozoic: The history of Earth's climate over the past 600 million years. 274 pp. Cambridge University Press, Cambridge.

FREY, R.C. 1989. Paleoecology of well-preserved nautiloid assemblages from a Late Ordovician shale unit, southwest Ohio. Journal of Paleontology 63, 604-620.

GNOLI, M. 1990. New evidence for faunal links between Sardinia and Bohemia in Silurian time on the basis of nautiloids. Bollettino della Societá Paleontologica Italiana 29, 289-307.

GNOLI, M. 1993. Remarks on minor elements of the Upper Silurian cephalopod fauna of SW Sardinia. Atti della Societá naturali i matematicali di Modena 124, 27-34.

GNOLI, M. 2003. Northern Gondwanan Siluro-Devonian palaeogeography assessed by cephalopods. Palaeontologia Electronica 5(2), 1-19.

GÜRICH, G. 1908. Leitfossilien. I. Kambrium und Silur. 96 pp. Verlag von Gebrüder Borntraeger, Berlin.

HAMAdA, T., TANABE, K. \& HAYASAKA, S. 1980. The first capture of a living chambered Nautilus in Japan. Science Paper of the Collegiums General Education, University of Tokyo 30, 63-66.

HAVLÍČEK, V. 1995. New data on the distribution of brachiopods in the Motol and lowest Kopanina Formations (Wenlock, lower Ludlow, Prague Basin, Bohemia). Věstník Českého geologického ústavu 70(4), 47-63.

HAVLíčEK, V. ed. 1987. Vysvětlivky k základni geologické mapě ČSSR, 1 : 25 000, list Beroun 12-411. 100 pp. Ústřední ústav geologický, Praha.

HAVLÍČEK, V. \& ŠTORCH, P. 1990. Silurian brachiopods and benthic communities in the Prague Basin (Czechoslovakia). Rozpravy Ústředního ústavu geologického 48, 1-275.

HAVlíčEK, V., VANĚK, J. \& FATKA, O. 1994. Perunica microcontinent in the Ordovician (its position within the Mediterranean Province, series division, benthic and pelagic associations). Sborník geologických věd, Geologie 46, 23-56.

HedSTRÖM, H. 1917. Über die Gattung Phragmoceras in der Obersilurformation Gotlands. Sveriges Geologiska Undersökning 15, 1-35.

HEWITT, R.A. \& WATKINS, R. 1980. Cephalopod ecology across a late Silurian shelf tract. Neues Jahrbuch für Geologie und Paläontologie, Abhandlungen 160, 96-117.

Holland, C.H. 1984. Form and function in Silurian Cephalopoda. Special Papers in Palaeontology 32, 151-164.

Holland, C.H. 2000. Silurian cephalopods from the Pentland Hills. Scottish Journal of Geology 36, 177-186.

HOLLAND, C.H. \& STRIDSBERG, S. 2004. Specific representation 
of the Silurian cephalopod genus Phragmoceras in Gotland and Britain. Geologiska Föreningen Förhandlingar 126, 301-310.

HORNÝ, R. 1955. Studie o vrstvách budňanských v západní části Barrandienu. Sborník Ústředního ústavu geologického, Oddíl geologický 21(2), 315-447.

HyatT, A. 1883-1884. Genera of fossil cephalopods. Proceedings of the Boston Society of Natural History 22, 273-338.

HyatT, A. 1900. Cephalopoda, 502-592. In ZitTEL, K.A. \& EASTMAN, C.R. (eds) Text-book of Palaeontology. Volume 1. MacMillan \& Co., London.

JABLONSKI, D. 2001. Survival without recovery after mass extinctions. Proceedings of the National Academy of Sciences of the United States of America 99, 8139-8144. DOI 10.1073/pnas.102163299

JEPPSSON, L. 1990. An oceanic model for lithological and faunal changes tested on the Silurian record. Journal of the Geological Society of London 157(6), 1137-1148.

JEPPSSON, L. \& ALDRIDGE, R.J. 2002. Ludlow (late Silurian) oceanic episodes and events. Journal of the Geological Society of London 157(6), 1137-1148.

Johnson, M.E., Rong, J. \& KeRshaw, S. 1998. Calibrating Silurian eustasy against the erosion and burial of coastal paleotopography. New York State Museum Bulletin 491, 3-13.

KISELEV, G.N. 1984. Golovonogije molljuski silura i niznego devona severa Urala. 143 pp. Izdatel'stvo Leningradskogo Universiteta, Leningrad.

KISELEV, G.N. 1986. Nekatorye nautiloidei malinovskogo gorizonta silura podolii. Voprosy Paleontologii 1986, 86-96.

KISELEV, G.N. 1998. Silurskije cefalopody severnya Sibirii. 94 pp. Izdatel'stvo St. Peterburskogo Universiteta, St. Petersburg.

Kiselev, G.N., Mironova, M.G. \& SinitsinA, I.N. 1987. Atlas Silurskich molljuskov Podolii. 180 pp. Izdatelstvo Leningradskogo Universiteta, Leningrad.

KiseleV, G.N., SAVickyJ, J.V., Sinitsina, I.N. \& Mirnova, M.G. 1993. Atlas molljuskov $i$ brachiopod silura $i$ devona južnogo Tjan-Šanja. 115 pp. Izdatel'stvo St. Peterburskogo Universiteta, St. Petersburg.

KisElEV, G.N., SinYCINA, I.N. \& MiROnOVA, M.G. 1990. Atlas molljuskov verchego ordovika i silura severozapada Vostočno-Evropejskoj platformy. 77 pp. Izdatel'stvo St. Peterburskogo Universiteta, St. Petersburg.

KLUG, C. \& LEHMKUHL, A. 2004. Soft-tissue attachment structures and taphonomy of Middle Triassic nautiloid Germanonautilus. Acta Palaeontologica Polonica 49(2), 243-258.

KoKEN, E. 1896. Die Leitfossilien. 847 pp. C.H. Tarchnitz, Leipzig.

KoVANDA, J. ed. 1984. Vysvětlivky k základni geologické mapě ČSSR, $1: 25$ 000, list Rudná 12-412. 122 pp. Ústřední ústav geologický, Praha.

Ǩ̌íž, J. 1979. Silurian Cardiolidae (Bivalvia). Sborník geologických věd, Paleontologie 22, 1-160.

KŘíž, J. 1991. The Silurian of the Prague Basin (Bohemia) - tectonic, eustatic and volcanic controls on facies and faunal development, 179-203. In BASSETT, M.G., LANE, P.D. \& ED-
WARDS, D. (eds) The Murchison Symposium: proceedings of an international conference on The Silurian System. Special Papers in Palaeontology 44.

KŘíž, J. 1992. Silurian field excursions: Prague Basin (Barrandian), Bohemia. National Museum of Wales, Geological Series 13, 1-111.

KŘíž, J. 1998. Recurrent Silurian-Lowest Devonian cephalopod limestones of Gondwanan Europe and Perunica. New York State Museum Bulletin 491, 183-198.

KŘíž, J. 1999. Geologické památky Prahy. 278 pp. Czech Geological Survey, Prague.

KŘíž, J., DUFKA, P., JAEGER, H. \& SCHÖNLAUB, H.P. 1993. The Wenlock/Ludlow boundary in the Prague Basin (Bohemia). Jahrbuch der Geologischen Bundesanstalt 136, 809-839.

KRÖGER, B. 2007. Some lesser known features of the ancient cephalopod order Ellesmeroceratida (Nautiloidea, Cephalopoda). Palaeontology 50(3), 565-572. DOI 10.1111/j.1475-4983.2007.00644.x

KRÖGER, B. \& MUTVEI, H. 2005. Nautiloids with multiple paired muscle scars from Lower-Middle Ordovician of Baltoscandia. Palaeontology 48(4), 781-791. DOI 10.1111/j.1475-4983.2005.00478.x

KRS, M., PRUNER, P. \& MAN, O. 2001. Tectonic and paleogeographic interpretation of the paleomagnetism of Variscan and pre-Variscan formations of the Bohemian Massif, with special reference to the Barrandian terrane. Tectonophysics 332(1-2), 93-114. DOI 10.1016/S0040-1951(00)00251-1

KuHN, O. 1940. Paläozoologie im tablen. 50 pp. Gustav Fischer, Jena.

LEHNERT, O., ERIKSSON, M.J., CALNER, M., JOACHIMSKY, M. \& BUGGISCH, W. 2007. Concurrent sedimentary and isotopic indications for global climatic cooling in the Late Silurian. Acta Palaeontologica Sinica 46, 249-255.

LePorati, S.C., PeCl, G.T. \& SEmmens, J.M. 2007. Cephalopod hatchling growth: the effects of initial size and seasonal temperatures. Marine Biology 151, 1375-1383. DOI 10.1007/s00227-006-0575-y

LINNÉ, K. 1758. Systema naturae per regna tria naturae: secundum classes, ordines, genera, species, cum characteribus, differentiis, synonymis, locis. Editio Decima. 824 pp. Impensis Direct. Laurentii Salvii, Holmiae.

LOYDELL, D.K. 1998. Early Silurian sea-level changes. Geological Magazine 135(4), 447-471. DOI 10.1017/S0016756898008917

MANDA, Š. 1996. Cyrtograptus lundgreni Biozone in the southwestern part of the Svatý Jan Volcanic Centre (Wenlock, Prague Basin). Věstník Českého geologického ústavu 71(4), 369-374.

MANDA, Š. 2007. New Silurian nautiloids Phragmoceras Broderip, 1839 and Tubiferoceras Hedström, 1917 from the Prague Basin (Bohemia). Bulletin of Geosiences 82(2), 119-131. DOI 10.3140/bull.geosci.2007.02.119

MANDA, Š. \& BUDIL, P. 2007. Stop E1-6: Ludlow and early Přídolí succession at Mušlovka Quarry near Řeporyje; early Ludfordian radiation and the effect of the Ludfordian extinction events in the shallow-water carbonate succession, 25-34. 
In ELICKI, O. \& SCHNEIDER, E. (eds) Fossile Ökosysteme. Wissenschaftliche Mitteilungen, Institut für Geologie, Technische Universität Bergakademie Freiberg 34.

MANDA, Š. \& KŘíž, J. 2006. Environmental and biotic changes of the subtropical isolated carbonate platforms during Kozlowskii and Lau events (Prague Basin, Silurian, Ludlow). Geologiska Föreningen Förhandlingar 128, 161-168.

MANDA, Š. \& KŘíž, J. 2007. New cephalopod limestone horizon in the Ludlow (Gorstian, early L. scanicus Zone) of the Prague Basin (Bohemia, Perunica). Bollettino della Societá Paleontologica Italiana 46(1), 33-45.

MeleChIn, J.M., Koren, T.N. \& ŠTorCH, P. 1998. Global Diversity and survivorship patterns of Silurian Graptoloids. New York State Museum Bulletin 491, 165-181.

MiLleR, A.K. \& FURNISH, W.M. 1937. Paleoecology of Paleozoic cephalopods. National Research Council, Committee on Paleoecology, Report 1936-1937, 54-63. National Research Council, Washington.

MilleR, A.K. \& YoungQuist, W. 1949. The Maquoketa coquina of cephalopods. Journal of Paleontology 23, 199-204.

MiLleR, S.A. 1877. The American Palaeozoic Fossils: a catalogue of the genera and species with names of authors, dates, places of publication, groups of rocks in which found, and the etymology and signification of the words and an introduction devoted to the stratigraphical geology of the Palaeozoic rocks. 123 pp. Published privately, Cincinnati, Ohio.

MoORE, R.C. ed. 1964. Treatise on Invertebrate Paleontology, Part K, Mollusca 3. 519 pp. Geological Society of America, Lawrence.

MURCHISON, R.I. 1839. The silurian system, founded on geological researches in the counties of Salop, Hereford, Radnor, with descriptions of the coal fields and overlying formations. Part 1. 768 pp. John Murray, London.

MUTVEI, H. 1964. Remarks on the anatomy of Recent and fossil Cephalopoda. Stockholm Contributions on Geology 11, 79-102.

Noetling, F. 1884. Beiträge zur Kenntniss der Cephalopoden aus Silurgeschieben der Provinz Ost-Preussen. Jahrbuch der Königlich Preussischen Geologischen Landesanstalt und Bergakademie der Berlin 1883, 101-135.

PIA, J. 1923. Über die ethologische Bedeutung einiger Hautzüge in der Stammesgeschichte der Cephalopoden. Annalen des Naturhistorisches Museum Wien 36, 50-73.

PRANTL, F. 1952. Zkameněliny českých pramoři. 321 pp. Vesmír, Praha.

PrELl, H. 1921. Die biologische Bedeutung der Mündungsverengung bei Phragmoceras. Centralblatt für Mineralogie, Geologie und Paläontologie für 1921, 305-315.

REYMENT, R.A. 1958. Some factors in the distribution of fossil cephalopods. Stockholm Contributions in Geology 1(6), 97-184.

RöHLICH, P. 2007. Structure of the Prague Basin: The deformation diversity and its causes (the Czech Republic). Bulletin of Geosciences 82(2), 175-182.

RUZHENCEV, V.E. ed. 1962. Osnovy Paleontologyi, Golovonogie I. 438 pp. Izdatel'stvo Akademii nauk, Moskva.
Shigeno, S., Sasaki, T., Moritaki, T., Kasugai, T., VecChione, M. \& AGATA, K. 2008. Evolution of the Cephalopod Head Complex by Assembly of Multiple Molluscan Body Parts: Evidence from Nautilus Embryonic Development. Journal of Morphology 269, 1-17. DOI 10.1002/jmor.10564

SOWERBY, J.C. 1816. The mineral conchology of Great Britain. Volume 2. Published privately, London.

SOWERBY, J.C. 1839 in MURCHISON, R.I. 1839. The silurian system, founded on geological researches in the counties of Salop, Hereford, Radnor, with descriptions of the coal fields and overlying formations. Part 1. 768 pp. John Murray, London.

STANLEY, S.M. 1970. Relation of shell form to life habits of the Bivalvia (Mollusca). Geological Society of America Memoir 125, 1-296.

STENZEL, H.B. 1964. Living Nautilus, 59-93. In MoORE, R.C. (ed.) Treatise on Invertebrate Paleontology, Part K, Mollusca 3. The Geological Society of America, Lawrence.

STRIDSBERG, S. 1985. Silurian oncocerid cephalopods from Gotland. Fossils and Strata 18, 1-65.

STRIDSBERG, S. 1988. A stray cephalopod in the late Silurian of Sardinia. Bollettino della Societá Paleontologica Italiana 27(1), 83-85.

STRIDSBERG, S. \& TUREK, V. 1997. A revision of the Silurian nautiloid genus Ophioceras Barrande. Geologiska Föreningen Förhandlingar 119, 21-36.

SvobodA, J. \& PrAnTL, F. 1948. O stratigrafii a tektonice staršího paleozoika v okolí Chýnice. Sborník Státního geologického ústavu, Oddíl geologický 15, 1-39.

SWEET, W.C. 1959. Muscle attachment impressions of some Paleozoic nautiloid cephalopods. Journal of Paleontology 33, 293-305.

SweET, W.C. \& Miller, A.K. 1957. Ordovician cephalopods from Cornwallis and Little Cornwallis islands, District of Franklin, Northwest Territories. Bulletin of the Geological Survey of Canada 38, 1-86.

TASCH, P. 1955. Paleoecologic observations on the orthoceratid coquina beds of the Maquoketa at Graf, Iowa. Journal of Paleontology 29(3), 510-518.

TEICHERT, C. 1964. Morphology of hard parts, 313-353. In MOORE, R.C. (ed.) Treatise on Invertebrate Paleontology, Part K, Mollusca. Geological Society of America, Lawrence. TEICHERT, C. 1970. Drifted Nautilus shells in the Bay of Bengal. Journal of Paleontology 44(6), 1129-1130.

TEICHERT, C. 1988. Main features of cephalopod evolution, 11-79. In Clarke, M.R. \& TRUEMAN, E.R. (eds) The Mollusca, vol. 12, Paleontology and Neontology of Cephalopods. Academic Press, San Diego.

TUREK, V. 1974. Poznámky k sedimentaci „ortocerových vápencü“ Barrandienu (Remarks on sedimentation of "orthoceratid limestones" in the Barrandian). Časopis pro mineralogii a geologii 19(2), 165-169.

TUREK, V. 1976. Magdoceras gen. n. and Inclytoceras gen. n. from the Silurian of central Bohemia (Nautiloidea, Barrandeocerida). Časopis pro mineralogii a geologii 21(2), $137-145$. 
TUREK, V. 2007. Systematic position and variability of the Devonian nautiloids Hercoceras and Ptenoceras from the Prague Basin (Czech Republic). Bulletin of Geosciences 82(1), 1-10.

WARD, P.D. 1987. Natural history of Nautilus. 263 pp. Allen \& Unwin, Boston.

WESTERMANN, G.E.G. 1998. Life habits of nautiloids, 263-298. In SAVAZZI, E. (ed.) Functional morphology of the invertebrate skeleton. John Wiley, London.

WILDE, P., BERRY, W.B.N. \& QUINBY, H.M.S. 1991. Silurian oceanic and atmospheric circulation and chemistry, 123-143.
In BASsetT, M.G., LANE, P.D. \& Edwards, D. (eds) The Murchison symposium; proceedings of an international conference on the Silurian System. Special Papers in Palaeontology 44.

ZOU XI-PING 1983. Silurian nautiloids from Bateaobao, Darhan Muminglan Joint Banner, Inner Mongolia, 165-173. In LI WEN-GUO, RONG JIA-YU \& DONG DE-YUAN (eds) Silurian and Devonian rocks and faunas of the Bateaobao Area in Darhan Mumingan Joint Banner, Inner Mongolia. The People's Publishing House of Inner Mongolia, Nanjing.

\section{Appendix - List of referred sections}

1. Arethusina Gorge Section No. 687 (Praha, Velká Ohrada). Location: See Kř́̌̌z (1992), fig. 71. Motol Formation. Wenlock, Homerian, T. testis Zone: Bouček (1937), Kříž (1992), Křriž et al. (1993).

2. Braník U pivovaru Section (Praha, Braník). Location: see Kř́iž (1999), figure on p. 215. Motol Formation. Llandovery, Telychian, O. spiralis Zone: Kříž (1999).

3. Bubovitz e1. Barrande's locality, Czech modern name Bubovice. Type locality of Phragmoceras biimpresum. Location: exact site unknown. Motol Formation. Wenlock, Homerian, $T$. testis Zone (determined based on known fossils in Barrande's collection).

4. Butovice Na břekvici Section No. 584 (Praha, Butovice). Location: Kř́̌ž (1992), fig. 65. Kopanina Formation. Ludlow, Gorstian, early C. colonus Zone: Kříž (1992), Kříž et al. (1993).

5. Hinter Kopanina e2. Barrande's locality from which type material of Phragmoceras labiosum Barrande, 1865 and Phragmoceras longum Barrande, 1865 came. Exact sites unknown, one of them was probably in the Jiras Quarry area (see below).

6. Horní Desort Quarry (Praha, Zadní Kopanina). Location: locality No. 13, geological map $1: 25$ 000, sheet Rudná 12-412 (Kovanda ed. 1984). Kopanina Formation. Ludlow, Ludfordian: Svoboda \& Prantl (1948), Kř́ž (1999).

7. Konieprus e2. Barrande's locality. See Velký Hill Section.

8. Kosov Quarry, "new quarry", SW wall. Location: SW wall of the Kosov Quarry. Kopanina Formation. Ludlow, Gorstian, early S. chimaera Zone: Manda (unpublished data).

9. Kosov Quarry, "old quarry" (Beroun). Location. Kříž (1992), fig 28. Kopanina Formation. Ludlow, Ludfordian: Horný (1955), Kř́ž (1992).

10. Kovářovic mez Section (Praha, Butovice). Location: see Kř́̌̌z (1992), fig. 65. Kopanina Formation. Ludlow, lower-middle Ludfordian: Kř́iž $(1992,1999)$.

11. Liščí Quarry (Mořina). Location: Havlíček \& Štorch (1990), fig. 6. Kopanina Formation. Ludlow, Gorstian, S. chimaera Zone: Horný (1955), Havlíček \& Štorch (1990).

12. Lištice Herinky (Lištice). Location: Havlíček \& Štorch (1990), fig. 6. Motol Formation. Wenlock, Homerian, T. testis Zone: Havlíček \& Štorch (1990), Manda (1996).

13. Lištice U cestičky Section No. 759 (Lištice). Location: Kř́̌̌ (1992), fig. 48. Motol Formation. Wenlock, Homerian, T. testis Zone: Kř́iž (1992), Kř́iž et al. (1993), Manda (1996).

14. Lochkov e2. Barrande's locality. See below, Lochkov, Barrande's pit.
15. Lochkov, Barrande's pits (Praha, Lochkov). Barrande's locality Lochkov e2. Location: Kř́žž (1999), figure on p. 106. Kopanina Formation. Ludlow, Ludfordian: Kříž (1999). Remarks: old pits of fossil collectors, actually still covered with debris.

16. Mramorový Quarry Section No. 357 (Praha, Lochkov). Location: Kříž (1992), p. 90. Kopanina and Požáry formations. Ludlow, Ludfordian-Přídolí: Kří̌ (1992).

17. Mušlovka Quarry (Praha, Řeporyje). Location: Kř̌̌̌ (1992), fig. 71. Kopanina and Požáry formations. Ludlow-Přídolí: Bouček (1937), Kř́iž (1992, 1999), Manda \& Budil (2007).

18. Nová Ves, Hradiště II Section (Praha, Nová Ves). Location: Manda \& Kř́ž (2006), fig. 1. Ludlow, Ludfordian, N. kozlowskii and M. latilobus Zone: Manda (unpublished data), simplified section was published by Manda \& Budil (2007), fig. 20.

19. Nová Ves Gorge Section (Praha, Nová Ves). Location: see Bouček (1938). Motol Formation. Llandovery, Telychian, O. spiralis Zone: Bouček (1938). Remarks: inaccessible, studied fauna was obtained during sinking of well.

20. Požáry Quarry (Praha, К̌eporyje). Location: Kř̌iž (1992), fig. 71. Kopanina and Požáry formations. Ludlow-Přídolí: Kř́ǐz (1992, 1999), Carls et al. (2007).

21. Řeporyje Section No. 911 (Praha, Řeporyje). Location: see Bouček (1937), p. 9. Kopanina Formation. Ludlow, Ludfordian, lowermost $L$. scanicus Zone: briefly mentioned by Bouček (1937) and unpublished data (Kříž \& Manda 2006).

22. U elektrárny Section (Svatý Jan pod Skalou). Location: locality No. 14, geological map $1: 25$ 000, sheet Beroun 12-411 (Havlíček 1987). Motol Formation. Wenlock, Sheinwoodian, M. belophorus Zone: Havlíček \& Štorch (1990).

23. U lanovky Section (near to the town of Beroun). Location: Horný (1955), p. 349. Kopanina Formation. Ludlow, Ludfordian, S. linearis Zone: Horný (1955).

24. Velký Hill Section (Koněprusy). Location: locality No. 16, geological map 1 : 25 000, sheet Králův Dvůr 12-413 (Chlupáč 1987). Kopanina Formation. Ludlow, Ludfordian, S. linearis Zone: Horný (1955).

25. Vyskočilka e1 Section. Location: see Manda \& Kříž (2007), fig. 2. Kopanina Formation. Ludlow, Gorstian, early L. scanicus Zone.

26. Vyskočilka e2. Barrande's locality. Type locality of Phragmoceras imbricatum. See 25.

27. Zadní Kopanina, Jiras Quarry (Praha, Zadní Kopanina). Location: see Kříž (1999), figure on p. 242. Kopanina Formation. Ludlow, Ludfordian: Kř́iž (1999). 